\title{
Review Article \\ MicroRNAs in Gene Regulation: When the Smallest Governs It All
}

\author{
Dominique L. Ouellet, ${ }^{1,2}$ Marjorie P. Perron, ${ }^{1,2}$ Lise-Andrée Gobeil, ${ }^{1,2}$ \\ Pierre Plante, ${ }^{1,2}$ and Patrick Provost ${ }^{1,2}$ \\ ${ }^{1}$ Centre de Recherche en Rhumatologie et Immunologie, Centre de Recherche du CHUL, 2705 Boulevard Laurier, \\ Ste-Foy, Quebec, Canada G1V 4 G2 \\ ${ }^{2}$ Faculté de Médecine, Université Laval, Quebec, Canada G1K 7P4
}

Received 30 January 2006; Accepted 17 April 2006

\begin{abstract}
Encoded by the genome of most eukaryotes examined so far, microRNAs (miRNAs) are small 21-nucleotide (nt) noncoding RNAs (ncRNAs) derived from a biosynthetic cascade involving sequential processing steps executed by the ribonucleases (RNases) III Drosha and Dicer. Following their recent identification, miRNAs have rapidly taken the center stage as key regulators of gene expression. In this review, we will summarize our current knowledge of the miRNA biosynthetic pathway and its protein components, as well as the processes it regulates via miRNAs, which are known to exert a variety of biological functions in eukaryotes. Although the relative importance of miRNAs remains to be fully appreciated, deregulated protein expression resulting from either dysfunctional miRNA biogenesis or abnormal miRNA-based gene regulation may represent a key etiologic factor in several, as yet unidentified, diseases. Hence is our need to better understand the complexity of the basic mechanisms underlying miRNA biogenesis and function.
\end{abstract}

Copyright (C) 2006 Dominique L. Ouellet et al. This is an open access article distributed under the Creative Commons Attribution License, which permits unrestricted use, distribution, and reproduction in any medium, provided the original work is properly cited.

\section{INTRODUCTION}

In 1990, a group of plant biologists attempted to accentuate the purple pigmentation of petunia petals by increasing the synthesis of anthocyanin via overexpression of a transgene encoding chalcone synthase. Unexpectedly, this transgene induced the formation of white flowers, in association with a block in pigment synthesis and a 50-fold reduction in transgene mRNA levels; this intriguing phenomenon was termed cosuppression $[1,2]$.

Three years later, in the field of developmental biology, Lee et al [3] identified two lin-4 transcripts, with the smaller $(\sim 21 \mathrm{nt})$ being complementary to seven repeated sequences in the $3^{\prime}$ nontranslated region (NTR) of the heterochronic gene lin-14 mRNA, identified previously by Wightman et al [4]. These findings suggested that lin- 4 could regulate lin-14 translation via an antisense RNA:mRNA interaction and play an important role in developmental timing in the nematode Caenorhabditis elegans (C elegans) $[3,5]$.

These studies converged in 1998, when Fire et al [6] obtained evidences about the involvement of double-stranded (ds) RNA intermediates in a phenomenon termed RNA interference (RNAi). The authors noticed that dsRNA species induced a more potent genetic interference than either strands alone in $C$ elegans. A year later, while investigating posttranscriptional gene silencing (PTGS) as a natural antiviral defense mechanism, Hamilton and Baulcombe [7] observed the presence of antisense viral RNA of $\sim 25 \mathrm{nt}$ in virusinfected plants. The authors noted that these small RNAs were long enough to convey sequence specificity and suggested that they may be important specificity determinants of PTGS. Subsequent papers reporting that dsRNA-induced mRNA degradation is mediated by 21 to $23 \mathrm{nt}$ RNAs $[8,9]$ prompted molecular biologists and geneticists to search for the endogenous source of small RNAs. In 2001, three independent groups defined miRNAs as a novel family of small $(\sim 22 \mathrm{nt})$ endogenous RNAs that are diverse in sequence and expression patterns, evolutionarily widespread, and involved in sequence-specific, posttranscriptional regulatory mechanisms of gene expression [10-12].

We now know that miRNA genes are encoded in the genome of most eukaryotic organisms and transcribed by RNA polymerase (pol) II into primary miRNAs (primiRNAs). These structured RNAs are then processed by the nuclear RNase III Drosha, acting in concert with the DiGeorge syndrome critical region 8 (DGCR8) protein within a 


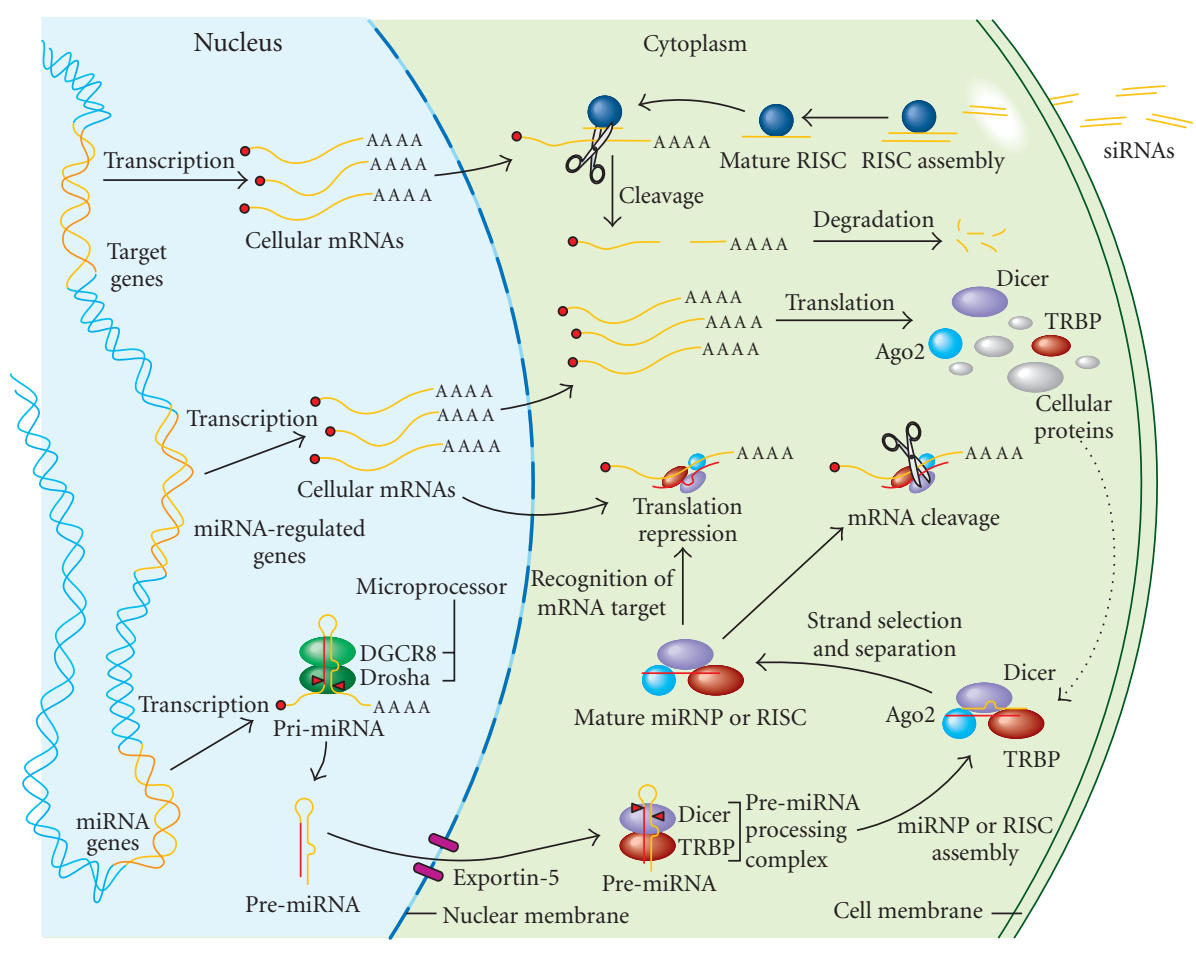

FIGURE 1: mRNA regulation mediated by microRNAs (miRNAs). miRNA genes are transcribed by RNA polymerase II into primary miRNAs (pri-miRNAs), which are processed by Drosha, acting in concert with DiGeorge syndrome critical region 8 (DGCR8) protein within the microprocessor complex, into $\sim 60$ to $70 \mathrm{nt}$ miRNA precursors (pre-miRNAs). Following export via exportin-5, pre-miRNAs are cleaved by Dicer, acting in concert with transactivating response RNA-binding protein (TRBP) within the pre-miRNA processing complex, to generate an imperfect miRNA:miRNA* duplex of $\sim 21$ to $23 \mathrm{nt}$. After a strand selection/separation process, the mature miRNA is loaded into an effector miRNA-containing ribonucleoprotein (miRNP) complex that will recognize and mediate repression or cleavage of specific mRNAs. Synthetic small interfering RNAs (siRNAs) can be introduced into cells and be incorporated into the endogenous miRNA-guided RNA silencing machinery to mediate cleavage of the targeted mRNA.

complex known as the microprocessor [13-16], into $\sim 60$ to $70 \mathrm{nt}$ stem loop miRNA precursors (pre-miRNAs) [1719]. Following export from the nucleus to the cytoplasm by the Ran-GTP dependent transporter Exportin-5 [20-23], the pre-miRNAs are cleaved at the base of the loop by a second RNase III enzyme located in the cytoplasm, Dicer, to generate an imperfect miRNA:miRNA* duplex of $\sim 21$ to $24 \mathrm{nt}$. Dicer was recently shown to act together with the transactivating response RNA-binding protein (TRBP) within a pre-miRNA processing complex. Following strand selection/separation, mature $\sim 22 \mathrm{nt}$ miRNAs are incorporated into, and guide, effector miRNA-containing ribonucleoprotein (miRNP) complexes containing Argonaute 2 (Ago2) towards specific mRNAs. Dicer and TRBP have recently been shown to be a part of a functional human RNA-induced silencing complex (RISC), thereby coupling the initiation and effector steps of RNAi [24]. The targeted mRNA will be initially subjected either to cleavage or translation repression, depending on whether the miRNA:mRNA pairing is perfect or not [25]. The miRNA-guided RNA silencing pathway is illustrated in Figure 1.

In humans, conservative predictions indicate that up to $30 \%$ of the genes may be regulated by such a mechanism! Thus, potentially all the cellular pathways may be governed by miRNAs, which may contribute to the fine tuning of gene expression on a global level. The importance of miRNAs in gene regulation will be better appreciated when their function or deregulation, or that of the cellular machinery mediating their biosynthesis and function, will be identified among the underlying causes of several genetic disorders. Indeed, it is easy to conceive that protein overexpression resulting from defective miRNA-based mRNA regulation may compromise normal cell function and cause genetic diseases. In turn, the responsible gene(s) may be responsive to RNAibased inactivation, illustrating the transition from fundamental research to clinical applications of RNAi.

Today, the miRNA mimetics small interfering RNAs (siRNAs) are increasingly important molecular tools, as they often are the method of choice used by researchers that aim at elucidating the function of a gene. More importantly, perhaps, is the high potential of the approach for therapeutic applications, leading several biotechnology firms to develop and refine tools, and improve the design of new therapeutic strategies in order to take advantage of the natural RNA silencing machinery to silence the expression of disease-causing genes. This requires a better understanding of the miRNA-based RNA silencing machinery in human. 


\section{COMPONENTS OF THE RNAI MACHINERY}

The endogenous miRNA-guided RNA silencing machinery is composed of several different proteins, protein complexes, and types of RNAs. How these elements integrate with each other to form this important functional cascade is the subject of intense investigations. We will first discuss the protein components, identified so far, that are governing miRNA biogenesis and function (see Figure 1). The subsequent sections will cover the identification of miRNAs and their targets, the biological roles of miRNAs, as well as their involvement in diseases.

\section{RNA polymerase II}

RNA pol II, which governs the transcription of proteinencoding messenger RNAs (mRNAs), has been identified as the major transcriptional unit for miRNA genes $[17,26]$ after some speculations about the potential implication of RNA pol III [25]. The pri-miRNA transcripts, which can be longer than 1000 nts [26] and up to several kilobases long, possess the signature of RNA pol II characterized by a 5' 7-methyl guanylate $(\mathrm{m} 7 \mathrm{G})$ cap and a $3^{\prime}$ poly(A) tail [17]. Although miRNA genes can be found as clusters forming their own transcriptional units $[19,26], \sim 40 \%$ are transcribed from the intronic sequence of protein-encoding genes [27, 28]. A study by Rodriguez et al [27] has shown that the expression of a large subset of mammalian miRNAs may be transcriptionally linked to the expression of other genes, coding for both proteins and ncRNAs. Although the majority of pri-miRNAs are noncoding RNAs, whose genomic regions do not correlate with known transcripts [29], some of them contain open reading frame (ORF) susceptible to be translated. However, analysis of both endogenous and overexpressed pri-miRNAs showed that very little full-length primiRNA transcripts reached the cytoplasm, probably because they were processed by Drosha before they could be exported from the nucleus [17].

\section{Drosha}

The RNase III Drosha is a class II endoribonuclease that was identified, cloned, and first implicated in preribosomal RNA (pre-rRNA) processing [30] (see Figure 2). Members of the class II RNase III family are characterized by a duplication of the RNase III domain (RIIID), a C-terminal dsRNA binding domain (dsRBD), as well as a proline-rich region (PRR) and an arginine/serine(RS)-rich domain in the $\mathrm{N}$-terminal region $[18,30]$. Previously known as the human RNase III, Drosha was further identified as the enzyme mediating the first step in miRNA biogenesis through conversion of primiRNAs into pre-miRNAs [18] (see Table 1), confirming previous findings obtained with nuclear fractions of human cultured cells [19].

Drosha homologues are expressed in C elegans $[13,31]$, Drosophila melanogaster (D melanogaster) $[13,31]$, and Mus musculus [32], but not in Schizosaccharomyces pombe (S pombe) (http://www.sanger.ac.uk/Projects/S_pombe/) and
Arabidopsis thaliana (A thaliana) [30]. The absence of Drosha in lower species reveals fundamental differences in the initiation steps of small regulatory RNA biosynthesis, which may have been evolved during the course of evolution.

Pri-miRNA processing by Drosha yields a pre-miRNA product with termini bearing the signature of RNases III, that is, a $5^{\prime}$ phosphate and $2 \mathrm{nt}$ overhangs at the $3^{\prime}$ hydroxylated end $[18,19,33]$. From the junction of the loop and the adjacent stem, Drosha cleaves pri-miRNAs after approximately two helical turns into the stem to produce $\sim 70$ nt premiRNAs [18]. Lee et al used deletional mutagenesis on miR$30 \mathrm{a}$ followed by in vitro processing to show that sequences covering $\sim 20$ nt upstream and $\sim 25$ nt downstream of the expected cleavage site were necessary and sufficient to support processing [18]. Beyond the pre-miRNA cleavage sites, approximately one helix turn of stem extension is also essential for efficient processing. While Drosha cleavage sites are determined largely by the distance from the terminal loop, variations in stem structure and sequence around the cleavage site can fine-tune the actual cleavage sites chosen [34]. A cleaving model was proposed in which the two RIIID of Drosha form an intramolecular dimer to create a catalytic site for substrate processing [15]. This model is analogous to that proposed for Dicer [35]. The two RIIIDs of human Drosha are distinct in their roles within the dimer: the RIIIDa cuts the 3' strand, while the RIIIDb cleaves the $5^{\prime}$ strand, independently of each other [15]. Han et al suggested that Drosha may reorientate itself after the recognition of the $3^{\prime}$ end of pri-miRNAs [15] and, as for human Dicer, places the processing center at $<20$ base pairs from the terminus [35].

Fractionation of HEK 293 cell nuclear extracts by gel filtration chromatography identified a pri-miRNA processing activity corresponding to a molecular mass of $>700 \mathrm{kDa}$ [15]. This activity peak shifted to $<650 \mathrm{kDa}$ following treatment of the extract with RNase A, indicating that Drosha may function in a large complex of $<650 \mathrm{kDa}$. Analysis of Drosha immunoprecipitates by mass spectrometry revealed the presence of DGCR8 in that complex [13, 14]. A distinct, larger Drosha complex containing the DEAD box RNA helicase DDX17/P72, the heterogeneous nuclear ribonucleoprotein M4 (hnRNPM4), and the protein product of Ewing's sarcoma gene (EWS) was reported [14]. As reviewed in Arvand and Denny [36], EWS belongs to a family of genes that encode proteins that may serve as adapters between the RNA pol II complex and RNA splicing factors. Because Drosha has also been previously shown to participate in pre-rRNA processing [30], this large Drosha complex has been suggested to mediate such pre-rRNA processing activities [14].

\section{DGCR8/microprocessor}

DGCR8 was identified in anti-Flag immunoprecipitates prepared from an HEK-293 cell line stably expressing FlagDrosha [14]. This Drosha-DGCR8 complex, which has also been observed in other organisms $[13,16]$, has been termed microprocessor [14]. DGCR8 contains two dsRBDs and a WW domain that could interact with the $\mathrm{N}$-terminal proline-rich region of Drosha [14]. 


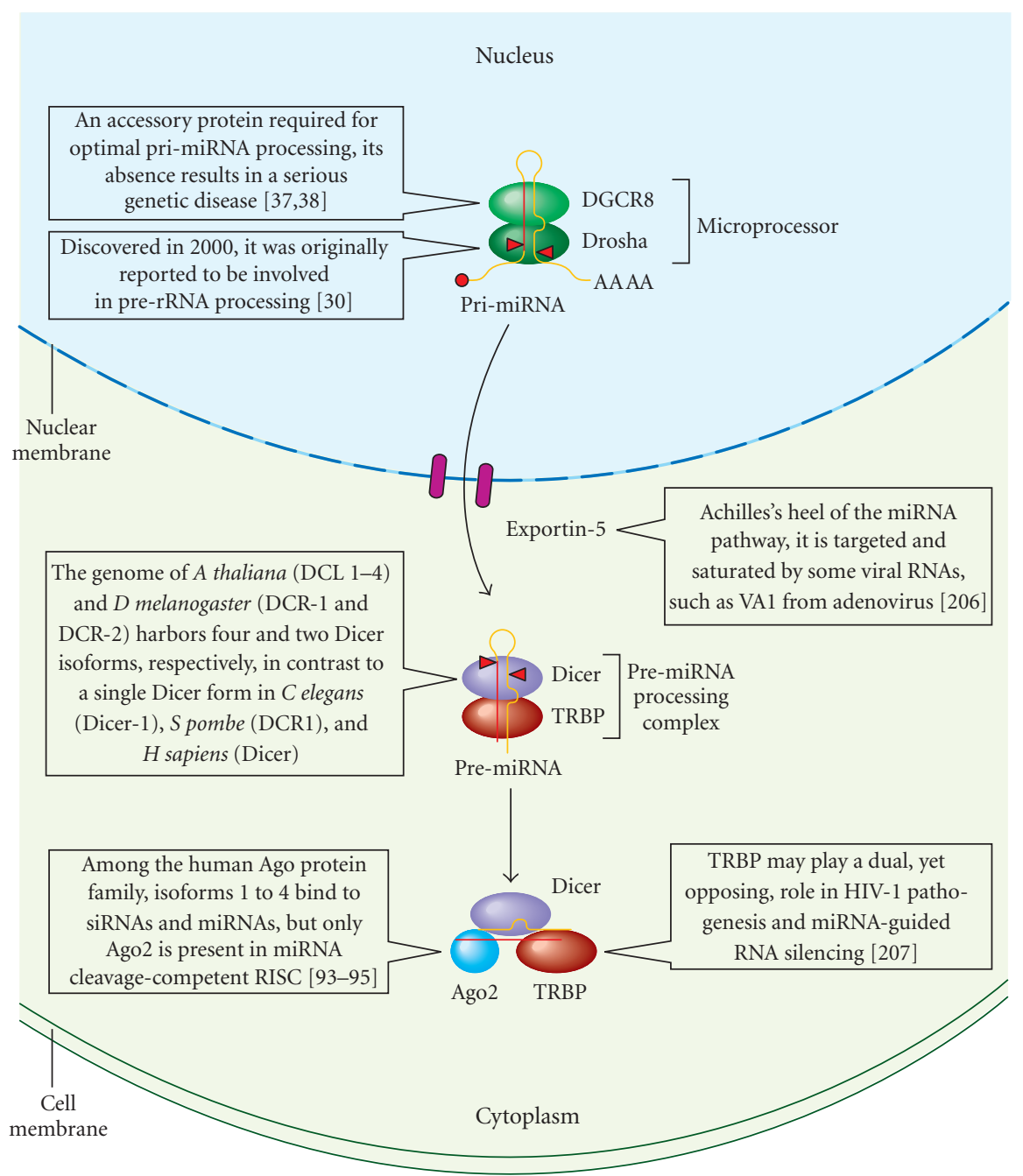

FIgURE 2: Some peculiarities of the major protein components of the microRNA-guided RNA silencing.

The exact role of DGCR8 in the microprocessor complex remains uncertain, but may be related to pri-miRNA recognition. In accordance with a proposed model, DGCR8 would interact with the stem, and perhaps also the singlestranded (ss) region of this structure, to guide the recognition of the pri-miRNA stem by Drosha dsRBD. Alternatively, but not exclusively, DGCR8 may also interact with the ss region of RNA to correctly orient the complex on pri-miRNAs [15]. Gregory et al [14] have shown that the knock-down of DGCR8 results in, as observed upon Drosha depletion, a pronounced decrease in mature miRNA level. Depletion of both Drosha and DGCR8 resulted in a substantial accumulation of pri-miRNAs, showing the requirement of the microprocessor complex for miRNA processing in vivo [14].

The DGCR8 gene is located in the q11.2 region of the human chromosome 22 that contains $\sim 30$ genes and is a part of a common monoallelic deletion [37]. Patients carrying this heterozygous deletion and other chromosomal abnormalities in this region display clinical phenotypes defined as the DiGeorge syndrome, Conotroncal anomaly face syndrome, and
Velocardiofacial syndrome [38]. Congenital heart defects, characteristic facial appearance, immunodeficiency, and behavioral problems are other manifestations of these genetic disorders [38].

\section{Exportin-5}

Subcellular localization studies previously showed that primiRNA and pre-miRNA processing is compartmentalized into the nucleus and cytoplasm, respectively [19], suggesting the existence of a pre-miRNA nuclear export step. Less than two years later, three independent groups reported the identification of Exportin-5, a member of the nuclear karyopherin $\beta$ transporter family [21], as the nuclear pre-miRNA transporter $[20,22,23]$.

Exportin-5-mediated pre-miRNA transport was either reduced upon downregulation of Exportin- 5 by siRNAs [23] or enhanced upon overexpression in mammalian cells [39]. Export of pre-miRNAs was greatly reduced by the inhibition of the Ran guanine nucleotide exchange factor, suggesting 
TABLE 1: Characteristics of the major protein components of the miRNA-guided RNA silencing pathway.

\begin{tabular}{|c|c|c|c|c|c|c|c|c|}
\hline Protein & $\begin{array}{c}\text { Role/ } \\
\text { function }\end{array}$ & $\begin{array}{l}\text { Accession } \\
\text { number } \\
(\mathrm{mRNA})\end{array}$ & $\begin{array}{l}\text { mRNA } \\
(\mathrm{bp})\end{array}$ & $\begin{array}{l}\text { Accession } \\
\text { number } \\
\text { (protein) }\end{array}$ & $\begin{array}{l}\text { Amino } \\
\text { acids }\end{array}$ & $\begin{array}{c}\text { Molecular } \\
\text { weight } \\
(\mathrm{kDa})^{*}\end{array}$ & $\begin{array}{l}\text { Isoelectric } \\
\text { point* }\end{array}$ & $\begin{array}{l}\text { Intracellular } \\
\text { localization }\end{array}$ \\
\hline Drosha & $\begin{array}{l}\text { Processing of } \\
\text { pri-miRNA into } \\
\text { pre-miRNA }\end{array}$ & NM_013235 & 4764 & NP_037367 & 1374 & 159 & 7.81 & Nuclear \\
\hline DGCR8 & $\begin{array}{l}\text { Assistance of Drosha } \\
\text { function in the } \\
\text { microprocessor }\end{array}$ & NM_022720 & 4461 & NP_073557 & 773 & 86 & 5.94 & Nuclear \\
\hline Exportin-5 & $\begin{array}{l}\text { Nuclear export } \\
\text { of pre-miRNA }\end{array}$ & NM_020750 & 5231 & NP_065801 & 1204 & 136 & 5.79 & Nuclear membrane \\
\hline Dicer & $\begin{array}{l}\text { Processing of pre-miRNA } \\
\text { into miRNA:miRNA* }\end{array}$ & NM_177438 & 10276 & NP_803187 & 1922 & 219 & 5.68 & Cytoplasmic, ER \\
\hline TRBP & $\begin{array}{l}\text { Assistance of Dicer } \\
\text { function in pre-miRNA } \\
\text { processing complex }\end{array}$ & M60801 & 1368 & AAA36765 & 345 & 38 & 7.38 & Cytoplasmic \\
\hline Ago2 & $\begin{array}{l}\text { Component of miRNPs, } \\
\text { repression of translation }\end{array}$ & NM_012154 & 3567 & NP_036286 & 859 & 97 & 9.19 & Cytoplasmic \\
\hline FMRP & $\begin{array}{l}\text { Component of miRNPs, } \\
\text { repression of translation }\end{array}$ & NM_002024 & 4362 & NP_002015 & 632 & 71 & 7.42 & $\begin{array}{l}\text { Cytoplasmic, } \\
\text { nuclear }\end{array}$ \\
\hline
\end{tabular}

*Calculated from protein calculator v.3.2 (http://www.scripps.edu/ cdputnam/protcalc.html). ER, endoplasmic reticulum.

that it is catalyzed by RanGTP [22]. In fact, RanGTP was necessary for specific binding of pre-miRNAs by Exportin5 [23]. Recognition of pre-miRNAs bearing a 2 nt $3^{\prime}$ overhang by Exportin- 5 was superior than pre-miRNAs with $5^{\prime}$ or no overhangs [40]. As for the pre-miRNA terminal loop and stem, which should be more than $16 \mathrm{nt}$ in length, their recognition is not sequence-specific $[20,40]$. Recognition of a minihelix motif in the RNA allows transport by Exportin5 , as demonstrated by the efficient transport of VA1 RNA from adenovirus 5 [41]. The exact coordination links between Exportin-5 and the nuclear and cytoplasmic steps of miRNA biogenesis remain obscure and need further investigation.

\section{Dicer}

Dicer is a ribonuclease III that was first identified as an enzyme capable of generating 21-23 nt RNA guide sequences from dsRNA to initiate RNAi in Drosophila S2 cells [42]. Within a two-month period, three papers reported that null mutations in the Dicer gene altered developmental timing, in association with defective miRNA maturation and accumulation of pre-miRNAs, in C elegans $[43,44]$ and Drosophila [45]. Human Dicer cDNA, which had been identified two years before [46], was later cloned and the recombinant protein expressed, allowing the characterization of its RNA binding properties and RNase activity $[47,48]$. Localized mainly in the cytoplasm [49] or the endoplasmic reticulum [47] of cultured cells, human Dicer is a large protein composed of several domains: an N-terminal putative ATPase/helicase do- main containing a DECH box, a domain of unknown function (DUF283), a PIWI/Ago/Zwille (PAZ) domain, and a Cterminal RIIID, composed of tandem RNase III motifs and a C-terminal dsRBD [35, 42, 47, 48].

Recently, data reported by Zhang et al [35] pointed towards the existence of a single catalytic center in human Dicer. The authors proposed a model in which Dicer would function through intramolecular dimerization of its two RIIID, assisted by the flanking RNA binding domains, PAZ, and dsRBD. The PAZ domain of Dicer may participate in the recognition of the terminal $3^{\prime}$ overhangs of its pre-miRNA substrate [35]. In this model, each RIIID cuts a single strand of the RNA duplex substrate after two turns of $\alpha$-helices, at the end opposite to that cleaved by Drosha, to produce a new end bearing a hydroxylated $2 \mathrm{nt} 3^{\prime}$ overhang and a phosphorylated $5^{\prime}$ end. The 2 nt overhang is measured by the alignment of the dimer rather than by the distance between active residues on one peptide chain, whereas the length of the product $(\sim 21 \mathrm{nt})$ is determined by the distance between the PAZ domain and the active site [35].

Genetic studies revealed that Dicer is essential for mammalian development, as Dicer-deficient mice die at the embryonic stage $[50,51]$. However, the DCR-1 gene can be disrupted in mouse embryonic stem (ES) cells by conditional gene targeting. The generated Dicer-null ES cells are viable, despite being completely defective in the generation of miRNAs, and display severe defects in differentiation both in vitro and in vivo [52]. Similar conditional inactivation of the Dicer gene in ES cell lines compromised proliferation as well as miRNA maturation, possibly rationalizing the phenotype 
observed in Dicer-null animals [53]. Epigenetic silencing of centromeric repeat sequences $[52,53]$ and expression of homologous small dsRNAs [52] were also markedly reduced in Dicer-null ES cells. Re-expression of Dicer in knockout cells rescued these phenotypes [52]. These results suggest the involvement of Dicer in multiple fundamental biological processes in mammals, ranging from stem cell differentiation to maintenance of centromeric heterochromatin structure and centromeric silencing [52].

It is relevant to note that Dicer activity is potently stimulated by limited proteolysis induced by low concentrations of proteinase $\mathrm{K}$ in vitro $[47,48]$, indicating the presence of intrinsic regulatory domains of Dicer activity. As recently reported, cellular proteins interacting with Dicer such as Ago2 [54], fragile X mental retardation protein (FMRP) [55], TRBP $[56,57]$, and the protein kinase R (PKR)-activating enzyme (PACT) [58] may also represent key regulators of Dicer activity. In addition, Dicer was recently shown to be a part of an effector miRNP [24], thereby coupling the initiation and effector steps of miRNA-guided RNA silencing.

\section{TRBP}

TRBP was identified and characterized in 1991 as a cellular factor acting in synergy with the viral Tat protein in the transactivation of the long terminal repeat (LTR) of human immunodeficiency virus type 1 (HIV-1), leading to viral gene transcription [59]. TRBP exists mainly in two different isoforms: TRBP1 and TRBP2 [60], which possess three dsRBDs and a basic C-terminus, coexist in the cell and are encoded by two alternatively initiated isoforms of mRNA that differ at their $5^{\prime}$ ends. TRBP2 is 21 amino acids longer than TRBP1 [60-62]. TRBP has also been shown to bind Tax of human T-cell leukemia virus 1 , although this interaction inhibits the transactivating activity of Tax [63]. Another function of TRBP is the inhibition of the interferon-induced dsRNAregulated PKR [64].

Recently, TRBP has been reported to play a role in miRNA-guided RNA silencing. TRBP was identified by proteomic analysis of immunoprecipitates prepared from HEK 293-derived stable cell lines expressing a Flag-tagged Dicer [56]. Further analyses revealed the association of DicerTRBP with Ago2 and the requirement of TRBP for the recruitment of Ago2 to the siRNA bound by Dicer. TRBP was shown to facilitate the cleavage of pre-miRNAs in vitro and optimize RNA silencing mediated by siRNAs and endogenous miRNAs [57]. These results support a role for TRBP, the first Dicer-interacting protein identified since Ago2, in assisting Dicer function in a pre-miRNA processing complex and contributing to RISC assembly by the recruitment of Ago 2 to the miRNA.

A Dicer interaction with the Drosophila homologue of human TRBP, Loquacious (Loqs), which share 34\% identity at the amino acid level, was also observed by two independent groups $[65,66]$. As for human TRBP, Loqs was required for normal processing of pre-miRNAs by Dicer-1 $[65,66]$ and for efficient miRNA-mediated silencing in various contexts [65]. Thus, every known fly RNase III is paired with a dsRBD-containing protein that facilitates its function in small RNA biogenesis.

\section{R2D2}

The siRNA-generating complex purified from Drosophila S2 cells consists of two stoichiometric subunits: Dicer-2 and R2D2 [67]. R2D2, which was named so because it contains two dsRNA-binding domains (R2) and is associated with DCR-2 (D2) in Drosophila [67], is homologous to $C$ elegans RDE-4 [68, 69]. The Dicer-2/R2D2 complex, but not Dicer-2 alone, binds to siRNA and enhances sequencespecific mRNA degradation mediated by the RISC. R2D2 has been shown to act as a biosensor for detecting thermodynamic differences of base pairing at the extremities of an siRNA [70]. Thus, in concert with Dicer-2, R2D2 determines which siRNA strand will be incorporated into the RISC and may also discriminate an impostor siRNA [71, 72]. These results indicate that R2D2 bridges the initiation and effector steps of the Drosophila RNAi pathway by facilitating siRNA passage from Dicer to RISC. Whether a similar mechanism is operating in humans remains to be investigated.

\section{RISC and miRNPs}

The miRNA or siRNA generated by Dicer is loaded into an effector miRNP or siRNP complex, respectively, and guides it for the recognition and regulation of the mRNA target. The mRNA specifically recognized by the RNP complexes will initially be either cleaved or translationally repressed, depending on whether the guide:mRNA pairing is perfect or not [25]. In humans, mRNA regulation by miRNAs is believed to consist mainly in translational repression, although a recent study reported that miRNAs downregulate a greater number of transcripts than previously thought [73]. Yekta et al [74] demonstrated that miR-196 shows perfect complementarity (presence of a single G:U wobble) with HOXB8 mRNA and directs its cleavage in mouse embryos. Genes for miR-196 map to homeobox (HOX) clusters, which encode transcription factors crucial for the developmental program in animals. Bagga et al [75] observed that the let-7 miRNA induces degradation of its target, lin-41, in $C$ elegans. Furthermore, they observed that the level of the lin- 4 miRNA targets, lin14 and lin-28, is decreased in response to lin-4 expression. These observations suggest that mRNAs containing partial miRNA complementary sites may not only be subjected to translational repression, but also be targeted for degradation in vivo.

Initial studies on the RISC reported the existence of a large $(\sim 150 \mathrm{kDa}$ to $\sim 500 \mathrm{kDa})$ multiprotein $\mathrm{RNP}$ complex exhibiting sequence-specific nuclease activity [54, 76, 77]. Small RNAs of $\sim 21$ to $25 \mathrm{nt}$ were found to copurify with the RISC isolated from Drosophila S2 cells [76], a characteristic shared by RISC complexes from other species [78]. A study by Pham et al [78] provided the first glimpse of the mechanism involved in RISC assembly. The authors proposed a three-step model for RISC formation in Drosophila. Isolation of three distinct complexes, named R1, R2, and R3, by native gel electrophoresis showed that siRNA binding to Dicer-2 is 
responsible for $\mathrm{R} 1$ formation. $\mathrm{R} 1$ is probably the $\sim 360 \mathrm{kDa}$ complex described as the RISC [77]. R1 serves as a precursor to form both the R2 and R3 complexes. R3 is a large ATPenhanced complex that contains unwound siRNAs, cofractionates with known RNAi factors, binds and cleaves targeted mRNAs in a cognate siRNA-dependent manner [78].

Recently, three studies published in the same issue of Cell $[24,79,80]$ provided additional insights on the composition, assembly, and function of the RISC. Gregory et al [24] showed that the human RISC is composed of at least three proteins: Dicer, TRBP, and Ago2. Recently, the dsRBD protein PACT was also found to be associated with Dicer, hAgo2, and TRBP in a $\sim 500 \mathrm{kDa}$ complex and to function as a component of the RISC [58]. At first, an ATP-dependent helicase was proposed to separate the two siRNA strands, one of which was thought to bind to Ago2. However, a recent consensus model suggests that Ago2 directly receives the doublestranded siRNA and cleaves the siRNA passenger strand instead, thereby liberating the ss guide for mediating cleavage or repression of the RNA target $[24,79,80]$. In contrast, passenger-strand cleavage is not important for the incorporation of miRNAs that are derived from mismatched duplexes, suggesting that this mechanism may not apply to endogenous miRNAs in humans.

In 2002, Mourelatos et al [81] reported the identification and characterization of a miRNP complex showing high similarity with the RISC. The authors isolated a wide range of different miRNAs forming a complex with three major proteins: Gemin3, Gemin4, and EIF2C2 (hAgo2). Gemin3, a $105 \mathrm{kDa}$ DEAD-box putative helicase, may be involved in unwinding the double-stranded miRNA and releasing the miRNA* strand for recognition of the target.

\section{P-/GW-bodies}

Where does the miRNP-mediated mRNA regulation or cleavage occur in the cell? Recent studies revealed the existence of specific cytoplasmic foci, referred to as processing (P-bodies) $[82,83]$ or GW182-containing bodies (GWbodies) [84]. The GW bodies, which were named so because they contain the GW182 RNA-binding protein, are enriched in proteins that are involved in mRNA degradation [85]. Liu et al [82] demonstrated the localization of Ago proteins into mammalian P-bodies. In fact, Ago proteins were found to interact with GW182 [86]. Silencing of GW182 or mutations that prevented Ago proteins from localizing in P-/GW-bodies impaired translational repression of mRNAs [86]. The presence of exogenous siRNAs was also detected in these bodies [87]. These studies support a functional link between cytoplasmic P-/GW-bodies and mRNA translation repression mediated by miRNAs.

These cytoplasmic P-/GW-bodies may not be the only sites of mRNA degradation in the cell. Two independent groups also detected a RISC-like activity in the nucleus of cultured mammalian cells $[88,89]$. It is tempting to speculate that the nuclear effector complex mediating this activity may be closely related to the RNA-induced initiation of transcriptional gene silencing (RITS) complex found in $S$ pombe [90].

\section{Ago2}

Ago2 is a member of the PAZ and Piwi domain (PPD) protein family, which is composed of highly basic proteins that are present in metazoans and fungi, but not in the budding yeast Saccharomyces cerevisiae [91, 92]. Eight members of the Ago family are expressed in humans [93], and the isoforms Agol to 4 are closely related. All four can bind siRNAs and miRNAs, but only Ago 2 is present in an mRNA-cleavage competent RISC $[94,95]$. Several paralogues of Ago proteins are found across the kingdoms and their number varies from 1 in $S$ pombe [96] to more than 20 in Celegans [43, 97].

Structural studies have provided key insights into the mechanism of RNAi. Ago2 is composed of a central PAZ domain and a C-terminal PIWI domain. The nuclear magnetic resonance solution structure of the Drosophila Agol PAZ domain bound to RNA was resolved recently [98, 99]. The structure consists of a left-handed, six-stranded $\beta$-barrel capped at one end by two $\alpha$-helices and wrapped on one side by a distinctive appendage, which comprises a long $\beta$-hairpin and a short $\alpha$-helix. Combined structural and binding studies of the PAZ domain indicated that it provides a binding pocket for the $3^{\prime}$ protruding ends of siRNAs [98-101].

Structural studies revealed that the PIWI domain consists of 5 -stranded $\beta$-sheets surrounded by three helices [102] and mediates binding of the ss RNA $5^{\prime}$ end [103-105]. The structure of Archaeoglobus fulgidus PIWI domain in complex with an siRNA-like duplex, which mimics the $5^{\prime}$ end of a guide RNA strand bound to an overhanging target mRNA, has been solved. This study revealed the presence of a highly conserved metal-binding site that anchors the $5^{\prime} \mathrm{nt}$ of the guide RNA [105]. Structural studies also determined PIWI as the catalytic domain for the nuclease activity of Ago2, given its resemblance to RNase $\mathrm{H}[95,102,104]$, in terms of structure and activity; like RNase $\mathrm{H}$, Ago 2 activity is dependent on divalent cations such as $\mathrm{Mg}^{2+}$ or $\mathrm{Mn}^{2+}$ [106]. The PIWI domain and RNase $\mathrm{H}$ also share a DDE motif, similar to those present at the catalytic center of integrase proteins [107].

Structural information from Pyrococcus furiosus Ago [102], together with the demonstration that Ago2 is the core slicing machine of the human RISC $[95,108]$, provided strong evidences suggesting that the PIWI domain may be responsible for mediating this "slicer" activity. This possibility was further supported by the observed inhibition of target mRNA cleavage activity upon deletion of the DDE motif of hAgo2 [95]. In siRNA-guided RNA silencing, Ago2 cleaves, in an ATP-independent manner, the phosphodiester backbone of the target mRNA between nucleotides 10 and 11, as calculated from the RNA guide 5' end [80, 94, 109].

The mechanism of translation repression mediated by Ago proteins is still unclear, although recent evidences suggest the possibility that some Ago-containing complexes may repress translation in P-bodies $[110,111]$.

\section{FMRP}

In human, loss-of-function mutations in the FMR1 (fragile mental retardation 1) gene product FMRP is the cause of the most common mental retardation, the fragile $\mathrm{X}$ syndrome 
$[112,113]$. An expansion of the CGG repeat in the $5^{\prime}$ NTR of FRM1 is associated with DNA methylation problems of both the CpG island and the CGG repeat itself, resulting in an inhibition of transcription and translation [114, 115].

FMRP is a cytoplasmic RNA-binding protein found to be associated with polyribosomes as part of an mRNA ribonucleoprotein (mRNP) complex, suggesting a role for FMRP in mRNA translation regulation [112]. In fact, this protein of 632 amino acids, containing two K-homology (KH) domains and an RGG box, acts as a negative regulator of translation in vitro and in vivo [116-118]. A relationship between FMRP and the RNAi pathway was unveiled by the copurification of dFMR1 with the Drosophila RISC, which also contains Ago2 and the vasa intronic gene (VIG) [119]. Similarly, Ishizuka et al [55] used a tandem affinity purification approach to isolate an RNP complex that contains dFMR1, Ago2, the RNA helicase Dmp68, and the ribosomal proteins L5/5S RNA and L11. Ishizuka's group demonstrated that dFMR1 is a component of the RISC effector complex and is associated with Dicer and Ago2 [55]. Knockdown of dFMR1 by introduction of dFMR1 dsRNA had only mild effects on the efficiency of RNAi $[55,119]$.

The work of Jin et al [120] suggested that FMRP could interact with miRNAs, Dicer, and Agol in mammalian cells in vivo, raising the possibility that FMRP could use miRNAs to regulate translation of specific mRNAs. Indeed, a recent study from our laboratory showed that human FMRP can act as an miRNA acceptor protein for Dicer and facilitate the assembly of miRNAs on specific target RNA sequences [121]. This activity appears to be mediated by the KH domains. In this study, the requirement of FMRP for efficient RNAi in vivo was unveiled by reporter gene silencing assays using various small RNA inducers, which also supported its involvement in an ss siRNP effector complex in mammalian cells. These results defined a possible role for FMRP in miRNA-guided RNA silencing and provided further insight into the molecular defects in patients with the fragile $\mathrm{X}$ syndrome.

\section{VIG}

The VIG protein has been shown to be associated with the Drosophila RISC [119]. An evolutionarily conserved protein expressed in $C$ elegans, $A$ thaliana, $S$ pombe, and mammals, VIG has no recognizable protein domains other than an RGG box, a motif that is known to bind RNA. Although no function has been assigned to VIG, its human homologue, plasminogen activator inhibitor (PAI)-RBP-1, was originally identified as a protein having an affinity for AU-rich elements (ARE) located in the $3^{\prime} \mathrm{NTR}$ of PAI RNA and regulating its stability [122]. The authors also demonstrated the importance of Dicer and miR-16, a human miRNA containing a sequence complementary to ARE, in conferring instability to ARE-containing mRNAs. This suggests an interesting connection between the components of the miRNA-guided RNA silencing pathway and regulation of the stability of mRNAs containing AREs, which are known to act in cis to regulate rapid turnover of unstable mRNAs [123] in their $3^{\prime}$ NTR. The exact role of VIG in that context remains to be investigated.

\section{Tudor-SN}

The staphylococcal nuclease Tudor (Tudor-SN) has been identified as a component of the RISC in $C$ elegans, $D$ melanogaster, and humans [124]. Tudor-SN contains five staphylococcal/micrococcal domains and a tudor domain. At first, Tudor-SN was suspected to be the nuclease responsible for the RISC-mediated mRNA target cleavage. However, studies demonstrating that the nuclease activity of the RISC is $\mathrm{Mg}^{2+}$ dependent [106] and produces $5^{\prime}$-phosphomonoester ends [125] did not support this hypothesis, as Tudor-SN is rather a $\mathrm{Ca}^{2+}$-dependant nuclease that generates $3^{\prime}$-phosphomonoand dinucleotides from DNA or RNA substrates [126].

Recently, a novel relationship was established between Tudor-SN and adenosine deaminases that act on RNA (ADARs). Members of the ADAR family exhibit affinity with dsRNAs and mediate an RNA editing reaction that substitutes adenosine (A) residues by inosines (I) in cellular mRNAs or other dsRNA targets [127]. Scadden [128] showed that Tudor-SN specifically interacts with and promotes the cleavage of model hyper-edited dsRNA substrates containing multiple IU and UI pairs. Yang et al [129] have recently reported that the edition of pri-miR-142 resulted in the suppression of its processing by Drosha, and was instead degraded by Tudor-SN. Similarly, pre-miRNAs have also been shown to be edited by ADARs [130]. ADAR-induced modification of pri- and pre-miRNA sequences may also contribute to diversifying and influencing the genetic control mediated by miRNAs. For example, structural changes induced by Ato-I edition of pri- and pre-miRNAs may hamper their recognition and processing by the dsRNA-cleaving Drosha and Dicer RNases [131-133]. These studies reveal a new function for RNA editing in the control of miRNA biogenesis.

\section{RITS complex}

In the fission yeast $S$ pombe, dsRNA arising from centromeric repeats targets the formation and maintenance of centromere function through RNAi-mediated histone H3 lysine-9 (K9) methylation [90]. This is accomplished by the effector complex RITS, which contains the proteins Ago1, Chp1, and Tas3, in addition to small RNAs [96] generated by Dicer [134]. Homologous to centromeric repeats [135], these small RNAs appear to guide the RITS components to heterochromatic regions, such as the centromeres, the mating-type region, and the telomeres $[136,137]$. Upon centromeric binding, RITS promotes Clr4-mediated methylation of histone H3 K9, recruitment of Swi6 [138], and formation of heterochromatin [96]. Recently, a study concluded that Dicer and the RNAi machinery were involved in the formation of heterochromatin in higher vertebrate cells, as suggested previously [134]. The discovery of the effector RITS complex supports a nuclear function for small RNAs derived from Dicer. 


\section{IDENTIFICATION OF miRNAs AND THEIR TARGETS}

As the major protein components of the miRNA-guided RNA silencing pathway are being identified and characterized, hundreds of new miRNAs are being discovered in several different species. The fact that the interaction between miRNAs and the mRNA targets they regulate is based mainly on partial, rather than perfect, complementarity renders target idenfication rather arduous. However, improvement of our understanding of the determinants governing mRNA recognition by miRNAs has allowed the development of several predictive bioinformatic tools. The growing number of miRNA targets and functions, as revealed by various experimental approaches, let us foresee the importance and complexity of the gene regulatory network utilizing miRNAs.

\section{Identification of miRNAs}

Almost 8 years after the discovery of the ncRNA lin-4, known for its crucial role in developmental timing in $\mathrm{C} \mathrm{el}$ egans $[3,5]$, three independent groups defined miRNAs as a novel family of small ( $\sim 22 \mathrm{nt})$ regulatory RNAs that are diverse in sequence and expression patterns, and evolutionarily widespread [10-12]. The authors used different strategies to identify new miRNAs from various species. miRNAs showing features reminiscent of Dicer cleavage can be cloned by reverse transcription-polymerase chain reaction (RT-PCR) on size-fractionated RNA populations. If their sequences are known or predicted, and if they are abundant enough, miRNAs can be detected by Northern blot analysis.

Rapid and large-scale identification of miRNAs prompted experts in the field to establish guidelines for miRNA annotation and institute different criteria, based on expression and biogenesis, for an RNA to be considered as an miRNA [139]. First, a 22 nt RNA transcript must be detected by Northern blot analysis. Second, the RNA transcript must be detected in a cDNA library prepared from size-fractionated RNA samples. Third, bioinformatic analyses must predict a hairpin-loop structure encoded in the genome and the sequence has to be located on one arm of this structure with a lowest free energy. The hairpin should have small bulges and approximately $60-80 \mathrm{nt}$ in length. Phylogenetic conservation among species represents another important feature which, however, excludes miRNAs that have either disappeared, appeared, or evolved during the course of evolution.

Computational algorithms designed to identify hairpinloop structures and sequence conservations across species are very useful, especially for less abundant or tissue-specific miRNAs. These small RNAs can be regrouped into families, based on the sequence of their $5^{\prime}$ region [139]. One computational algorithm that has been developed and tested with $C$ elegans, miRScan, uses different characteristics to identify miRNA genes. It has been designed to find conserved sequences upstream and downstream of the miRNA foldback, identify specific adjacent sequences that can be involved in miRNA transcription or processing, and determine the location of cotranscribed miRNAs in orthologous host genes [140].
miRBase is the new home of the miRNA data on the web, accessible at the following address: http://microrna.sanger .ac.uk/ [141]. It provides information previously accessible from the miRNA registry [142]. As of May 2006 (release 8.1), there were 462 human miRNA sequences among 3963 entries.

To date, miRNA genes constitute about $2 \%$ of the predicted genes in mammals. They may be constitutively or developmentally regulated and expressed at various levels in different tissues. Recent estimates suggest that between $30 \%$ and $50 \%$ of the genes may be regulated by miRNAs $[144,145]$. This raises the possibility that all the cellular pathways may be governed by miRNAs. However, the question remains: which mRNAs are subjected to miRNA regulation?

\section{Identification of miRNA targets}

Identification of miRNA targets is a key step in understanding the biological function of miRNAs. However, the progress of this work is hampered by the mode of mRNA recognition by the regulatory miRNAs itself, which is based on imperfect sequence complementarity [25]. Characterization of a few experimentally validated miRNA:mRNA interactions allowed to establish a context in which this interaction is favored and helped to develop very useful bioinformatic approaches to identify them. Initial studies indicate that a given miRNA may regulate several different mRNAs and that, conversely, a specific mRNA can be regulated by more than one miRNAs.

Several algorithms currently available on the web, such as TargetScan (http://genes.mit.edu/targetscan/) [146], Miranda (http://www.microrna.org) [147], and DIANAmicroT (http://www.diana.pcbi.upenn.edu/) [148], combine different parameters of the sequence requirements for miRNA:mRNA binding as predictive methods to identify targets. These computational tools are designed to scan the $3^{\prime}$ NTR of mRNA targets, to search for the miRNA seed and to determine the free energy of the interaction. They can also take into account the phylogenetic conservation and the presence of more than one miRNA binding site in a given $3^{\prime}$ NTR. Because each of these methods uses different miRNA:mRNA target predictive determinants, the results obtained may differ from one to another. Nevertheless, these bioinformatic tools are crucial in providing initial cues as to the possible mRNA targets regulated by specific miRNAs. They also offer a certain basis for initiating experimental validation on miRNA:mRNA target pair of interest. In turn, a better comprehension of the interaction between miRNAs and their targets will permit the improvement of these predictive methods.

Vella et al $[143,149]$ studied the well-characterized let7:lin-41 interaction to better understand the architecture and requirements of miRNA:mRNA target recognition. Although the lin-41 mRNA target bears six putative let-7 miRNA binding sites, only two of them appear to be necessary for lin41 regulation (see Figure 3). These two sites are separated by a $27 \mathrm{nt}$ sequence. Generally, the miRNA seed consists in a perfect pairing between miRNA nucleotides 2 to 8 with a 


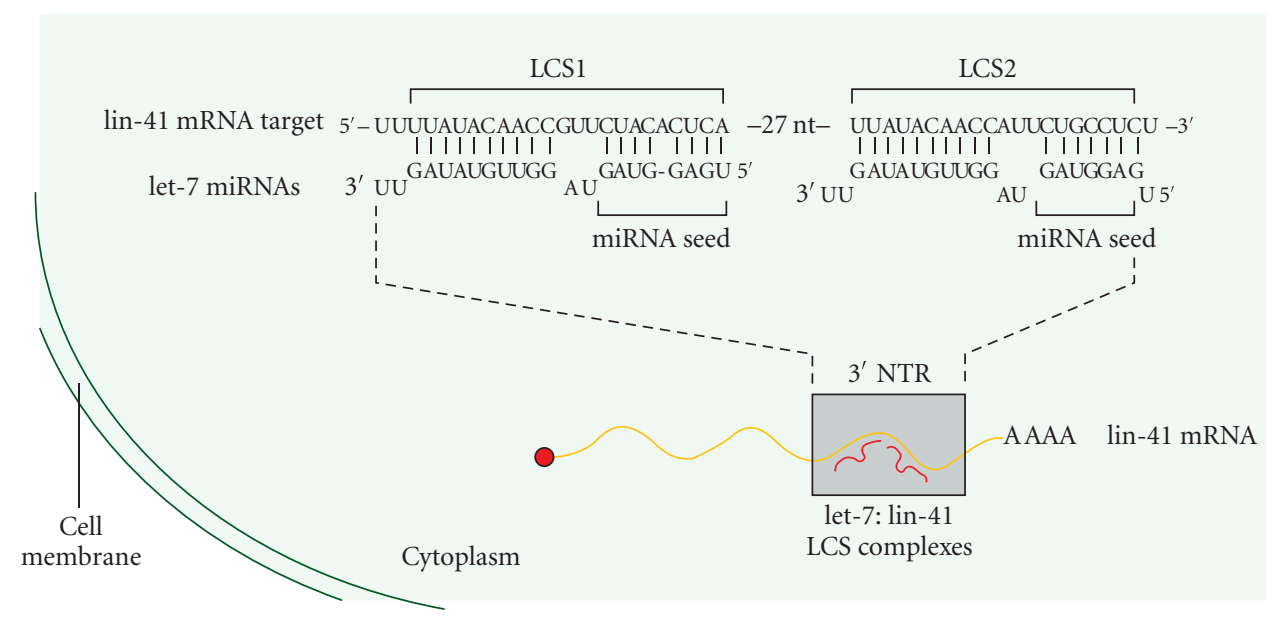

Figure 3: Recognition of the lin-41 mRNA by let-7 in C elegans. The lin-41 3'NTR contains two let-7 complementary sites (LCS) separated by a $27 \mathrm{nt}$ sequence that seems to be important in target recognition [143]. The miRNA seed consists in a perfect pairing of nucleotides 2 to 8 of the miRNA.

sequence located in the $3^{\prime}$ NTR of its mRNA target. Although pairing of the $3^{\prime}$ region of an miRNA seems to be less important, it may compensate a weaker binding of the $5^{\prime}$ region. The authors also observed that lin-41 regulation by let-7 was lost upon substitution of the intervening $27 \mathrm{nt}$ sequence by another [143]. This suggests that miRNA:mRNA interactions do not rely solely on the regions of complementarity and may be more complex than previously thought.

In spite of the difficulties to identify miRNA targets, several groups have found their way to assign a biological function to some miRNAs. Hematopoietic cell lineages derived from mouse bone marrow express specific miRNAs that regulate differentiation. Chen et al [150] analyzed three miRNAs, miR-181, miR-223, and miR-142 that were differentially or preferentially expressed in hematopoietic cells. They observed that overexpression of these miRNAs in undifferentiated progenitor cells derived from mouse bone marrow altered lineage differentiation. They further analyzed the effects of miR-181 in vivo by infecting mouse Lin $^{-}$bone marrow cells with a viral vector expressing this miRNA and observed that mice expressing miR-181 had a substantial increase in B-lymphoid $\left(\mathrm{CD} 19^{+}\right)$cells. Lim et al [73] used a microarray approach to identify miRNA targets after overexpression of known miRNAs. They found that 174 genes were downregulated following overexpression of miR-124, an miRNA preferentially expressed in the brain, in HeLa cells. Incidentally, the target genes were expressed at low levels in the brain. Thus, the expression of miR-124 in HeLa cells caused a shift in gene expression profile towards that of the brain. Using the same approach, expression in HeLa cells of miR-1, expressed in muscle, shifted the expression profile of HeLa cells towards that of the muscle.

\section{BIOLOGICAL FUNCTION OF miRNAs}

As experimental evidences are accumulating on how miRNAs recognize and regulate specific mRNA targets, we are be- ginning to understand the exact function of each miRNA as well as the cellular processes they are regulating. Information pertaining to the biological function of miRNAs in different species, which is the subject of this section, is summarized in Table 2 .

\section{miRNAs and development}

Developmental studies of the nematode $C$ elegans led to the discovery of the first small noncoding regulatory RNA, lin-4. $C$ elegans proceeds through four larval development stages termed L1 to L4. Transition from one stage to the next is dictated by temporally regulated heterochronic genes, which are involved in developmental regulatory cascades. Wightman et al [4] first reported that short repetitive sequences in the $3^{\prime}$ NTR of the heterochronic gene lin-14 were negative regulatory elements of Lin-14 expression. The observed increase in Lin-14 protein synthesis associated with two gainof-function mutations in the $3^{\prime} \mathrm{NTR}$ of lin-14 mRNA [4] was instrumental for this discovery. More than two years later, Lee et al [3] identified two lin-4 transcripts, one of 61 nt and another of $21 \mathrm{nt}$. Furthermore, they observed that the lin-4 smaller transcript was complementary to seven repeated sequences in lin-14 3'NTR, identified previously by Wightman et al [4]. These findings suggested that lin-4 could regulate lin-14 translation via an antisense RNA:mRNA interaction [3]. Recently, Boehm and Slack [169] found that lin-4 and lin-14 expression control life span through adulthood, since lin-4 loss-of-function mutant is associated with a shorter life span as compared to wild-type nematodes, whereas overexpression of lin-4 prolonged it. They also noted that animals carrying a temperature-sensitive loss-of-function mutation in lin-14 had a $31 \%$ longer life span than wild-type, which is consistent with the phenotype observed with lin-4 [169].

A second small ncRNA, let-7, was later identified and found also to regulate the transition from late larval L4 to adult stage through the regulation of heterochronic genes 
TABLE 2: Biological functions of miRNAs in different species.

\begin{tabular}{|c|c|c|c|c|c|c|c|}
\hline Species & Expression & miRNA & $\begin{array}{l}\text { mRNA } \\
\text { target }\end{array}$ & $\begin{array}{l}\text { Validation } \\
\text { (Expt/Pred) }\end{array}$ & $\begin{array}{l}\text { Mode of } \\
\text { regulation }\end{array}$ & Process regulated & References \\
\hline $\begin{array}{l}\text { Schizosaccharomyces } \\
\text { pombe }\end{array}$ & - & $\begin{array}{l}12 \text { different } \\
\text { small RNAs }\end{array}$ & $\begin{array}{l}\text { Centromeric } \\
\text { regions }\end{array}$ & Expt & $\begin{array}{l}\text { H3 K9 DNA } \\
\text { methylation }\end{array}$ & $\begin{array}{l}\text { Maintenance of } \\
\text { heterochromatin }\end{array}$ & {$[135]$} \\
\hline \multirow[t]{3}{*}{$\begin{array}{l}\text { Caenorhabditis } \\
\text { elegans }\end{array}$} & - & $\operatorname{lin}-4$ & $\begin{array}{l}\text { lin-14 } \\
\text { lin-28 }\end{array}$ & Expt & $\begin{array}{l}\text { Translational } \\
\text { repression/ } \\
\text { mRNA cleavage }\end{array}$ & $\begin{array}{l}\text { Control of the } \\
\text { developmental } \\
\text { stages L1-L3 }\end{array}$ & {$[3,4,75,151]$} \\
\hline & - & let-7 & $\begin{array}{l}\text { hbl-1 } \\
\text { lin-41 } \\
\text { daf-12 } \\
\text { ras }\end{array}$ & Expt & $\begin{array}{l}\text { Translational } \\
\text { repression/ } \\
\text { mRNA cleavage }\end{array}$ & $\begin{array}{l}\text { Control of the last } \\
\text { developmental } \\
\text { stage L4 }\end{array}$ & $\begin{array}{l}{[75,149,152-} \\
156]\end{array}$ \\
\hline & - & $\begin{array}{l}\operatorname{miR}-48 \\
\operatorname{miR}-84 \\
\operatorname{miR}-241\end{array}$ & hbl-1 & Expt & $\begin{array}{l}\text { Translational } \\
\text { repression }\end{array}$ & $\begin{array}{l}\text { Control of } \\
\text { the L2 to L3 } \\
\text { transition }\end{array}$ & [157] \\
\hline \multirow[t]{2}{*}{$\begin{array}{l}\text { Drosophila } \\
\text { melanogaster }\end{array}$} & - & bantam & hid & Expt & $\begin{array}{l}\text { Translational } \\
\text { repression }\end{array}$ & $\begin{array}{l}\text { Inhibition } \\
\text { of apoptosis }\end{array}$ & {$[158]$} \\
\hline & - & $\begin{array}{l}\text { miR-2 } \\
\text { miR-6 } \\
\text { miR-11 } \\
\text { miR-13 } \\
\text { miR-308 }\end{array}$ & $\mathrm{ND}$ & Expt & ND & $\begin{array}{l}\text { Inhibition of } \\
\text { apoptosis }\end{array}$ & [159] \\
\hline \multirow[t]{2}{*}{ Mus musculus } & $\begin{array}{l}\text { Hematopoietic } \\
\text { cells }\end{array}$ & $\begin{array}{l}\operatorname{miR}-142 \\
\operatorname{miR}-181 \\
\operatorname{miR}-223\end{array}$ & $\mathrm{ND}$ & Expt & ND & $\begin{array}{l}\text { Hematopoietic cell } \\
\text { differentiation }\end{array}$ & {$[150]$} \\
\hline & $\begin{array}{l}\text { Mouse embryo } \\
<\text { day } 7\end{array}$ & miR-196 & HOXB8 & Expt & mRNA cleavage & $\begin{array}{l}\text { Control of the } \\
\text { developmental } \\
\text { program }\end{array}$ & {$[74]$} \\
\hline \multirow[t]{7}{*}{ Homo sapiens } & Brain & $\operatorname{miR}-124$ & ND & Expt & ND & $\begin{array}{l}\text { Brain-specific } \\
\text { gene expression }\end{array}$ & {$[73]$} \\
\hline & Muscle & miR-1 & ND & Expt & ND & $\begin{array}{l}\text { Muscle-specific } \\
\text { gene expression }\end{array}$ & {$[73]$} \\
\hline & $\begin{array}{l}\text { Overexpression } \\
\text { in brain tumor } \\
\text { glioblastoma }\end{array}$ & $\operatorname{miR}-21$ & ND & Expt & ND & $\begin{array}{l}\text { Inhibition of } \\
\text { apoptosis }\end{array}$ & {$[160]$} \\
\hline & $\begin{array}{l}\text { Downregulation } \\
\text { in CLL }\end{array}$ & $\begin{array}{l}\text { miR-15a } \\
\text { miR-16-1 }\end{array}$ & $\mathrm{Bcl} 2$ & Expt & $\begin{array}{l}\text { Translational } \\
\text { repression }\end{array}$ & $\begin{array}{l}\text { Induction of } \\
\text { apoptosis }\end{array}$ & {$[161,162]$} \\
\hline & $\begin{array}{l}\text { Downregulation in } \\
\text { numerous cancer } \\
\text { cultured cells }\end{array}$ & $\begin{array}{l}\text { miR-143 } \\
\text { miR-145 }\end{array}$ & ND & Expt & $\mathrm{ND}$ & Oncogenesis & {$[163]$} \\
\hline & $\begin{array}{l}\text { Overexpression in } \\
\text { BL patient }\end{array}$ & miR-155 & ND & Expt & ND & Oncogenesis & {$[164]$} \\
\hline & $\begin{array}{l}\text { Overexpression in } \\
\text { B-cells lymphomas } \\
\text { and lung cancer } \\
\text { cell lines }\end{array}$ & $\begin{array}{l}\text { miR-17-92 } \\
\text { cluster }\end{array}$ & ND & Expt & ND & Oncogenesis & {$[165]$} \\
\hline
\end{tabular}


TABle 2: Continued.

\begin{tabular}{|c|c|c|c|c|c|c|}
\hline HeLa, 293T & miR-32 & $\begin{array}{l}\text { ORF2 in the } \\
3^{\prime} \text { NTR of all } \\
\text { remaining } \\
\text { PFV-1 } \\
\text { mRNAs }\end{array}$ & Expt & ND & $\begin{array}{l}\text { Restriction of } \\
\text { PFV-1 } \\
\text { accumulation }\end{array}$ & {$[166]$} \\
\hline $\begin{array}{l}\text { Liver-specific } \\
\text { expression }\end{array}$ & miR-122 & $\begin{array}{l}5^{\prime} \text { noncoding } \\
\text { region of the } \\
\text { HCV genome }\end{array}$ & Expt & ND & $\begin{array}{l}\text { Facilitation of } \\
\text { HCV replication }\end{array}$ & {$[167]$} \\
\hline $\mathrm{T}$ cells & $\begin{array}{l}\operatorname{miR}-29 a \\
\operatorname{miR}-29 b\end{array}$ & $n e f$ & Pred & ND & $\begin{array}{l}\text { Inhibition of HIV-1 } \\
\text { replication }\end{array}$ & {$[168]$} \\
\hline $\mathrm{T}$ cells & $\operatorname{miR}-149$ & $v p r$ & Pred & ND & $\begin{array}{l}\text { Control of the cell } \\
\text { cycle arrest } \\
\text { in G2 }\end{array}$ & {$[168]$} \\
\hline $\mathrm{T}$ cells & $\mathrm{miR}-378$ & env & Pred & ND & $\begin{array}{l}\text { Control of the virus } \\
\text { assembly }\end{array}$ & {$[168]$} \\
\hline $\mathrm{T}$ cells & miR-324-5p & vif & Pred & ND & $\begin{array}{l}\text { Control of } \\
\text { viral particle } \\
\text { production }\end{array}$ & {$[168]$} \\
\hline
\end{tabular}

BL: Burkitt lymphoma; CLL: chronic lymphocytic leukemias; Expt: experimental; HCV: hepatitis C virus; HIV-1: human immunodeficiency virus type 1; ND: not determined; PFV-1: primate foamy virus type 1; Pred: predicted.

in $C$ elegans [152]. Northern blot analyses revealed that the miRNA let-7 is expressed in a wide range of species, including worm, fly, and human, as opposed to lin-4, and seems to regulate late developmental transition in different species [153]. Three let-7 miRNA family members, miR-48, miR-84, and $\mathrm{miR}-241$, were identified on the basis of sequence identity of 8 consecutive nucleotides in their $5^{\prime}$ region $[11,170]$. let-7 regulates lin-41, hbl-1, and daf-12 [149, 152-155]. The other members of the let-7 family appear to regulate hbl1 in the L2 to L3 transition [157]. let-7 also appears to be important for zebrafish embryo development, since injection of a synthetic let-7 miRNA duplex into zebrafish zygotes causes severe growth defect [171]. Embryos of a maternalzygotic zebrafish Dicer mutant that were unable to process pre-miRNA into miRNA showed abnormal brain morphogenesis [172]. This brain defect was rescued by the injection of a preprocessed, mature miRNA, miR-430. The miRNA expression profile of zebrafish embryos is highly tissue-specific during segmentation and later stages, but not in early development, suggesting that miRNAs may play a more prominent role in differentiation or maintenance of tissue identity, rather than in directing tissue fate [173].

miRNAs have also a major role in developmental regulation in fly. This conclusion came from miRNA loss-offunction analyses using 2' O-methyl (Me) antisense oligoribonucleotides in Drosophila embryos [159]. In these analyses, depletion of as many as 25 of 47 miRNAs expressed in early development caused a severe developmental phenotype. In situ hybridization analyses, using probes recognizing 38 different miRNAs in Drosophila embryos, indicated that the expression profile of most of them is comparable to their vertebrate counterparts [174], suggesting an evolutionarily conserved role for miRNAs in development.

Recently, two groups independently reported the cloning of the mouse and chicken homologues of C elegans lin-41 $[175,176]$. They found that mlin-41 and clin-41 are implicated in limb development. Bioinformatic analyses confirmed the presence of let- 7 binding sites in the $3^{\prime}$ NTR of these two genes. In mice, targeted disruption of the Dicer 1 gene was lethal in early development, indicating that Dicer function is essential for proper development in mammals [50]. Harfe et al [177] used an inducible inactivation system of Dicer 1 to study its importance in late development in mice. In this model, depletion of Dicer led to a severe defect in limb formation.

\section{miRNAs and heterochromatin}

The RNAi pathway was also reported to play a role in nuclear events such as genome rearrangement [178], gene inhibition $[90,134,179]$, and chromosome segregation [134], supporting the idea that the genome integrity itself is preserved by small regulatory RNAs. In a model proposed by Noma et al [136], dsRNA transcripts are cleaved by Dicer to produce siRNAs, which are incorporated into the RITS complex and guide it to heterochromatic regions, probably through interactions with DNA or native RNA transcripts. Once localized at the siRNA homologous target sequence, the RITS complex recruits the Clr4 methyltransferase that catalyzes methylation of histone $\mathrm{H} 3$ at lysine 9. This creates binding sites for the heterochromatin protein Swi6 which, in turn, leads to the recruitment of additional $\mathrm{Clr} 4$ and further H3-Lys9 
methylation of adjacent nucleosomes. These modifications allow the binding of RITS in a Dicer-independant manner via the chromodomain of Chp1 and the maintenance of gene repression at the transcriptional level. Although this process was first documented in $S$ pombe $[96,136,180]$, recent reports indicate the occurrence of a similar transcriptional gene silencing phenomenon in the nucleus of human cells $[181,182]$. Altogether, these studies reveal a key role for Dicer-derived small RNAs in guiding the RITS complex and regulating the transcriptional and posttranscriptional status of host gene expression.

\section{miRNAs in cell growth and apoptosis}

Cell growth and programmed cell death are important processes implicated in both development and differentiation. The bantam gene identified in Drosophila was first discovered on the basis of its effect on tissue growth: tissues were larger when bantam was overexpressed and smaller when bantam expression was suppressed. Although smaller, the flies were proportional and did not exhibit patterning defects [158]. Later, the same group determined that the bantam gene encoded for an miRNA, not for a protein, that controlled the proapoptotic gene hid. Thus, bantam promotes proliferation while inhibiting apoptosis [183]. Additional miRNAs involved in the regulation of pro-apoptotic genes in Drosophila were discovered in loss-of-function experiments. In that context, a family of miRNAs comprising miR-2, miR-6, miR-11, miR-13, and miR-308 has been found to be required for suppression of embryonic apoptosis [159].

Chang et al [184] used a library of miRNA antisense oligonucleotides bearing 2' O-Me modifications to inhibit miRNA function in HeLa cells. Monitoring changes in cell growth and apoptosis, they identified several important regulatory miRNAs. In the highly malignant human brain tumor glioblastoma, miR-21 was strongly overexpressed. When miR-21 was knocked down in glioblastoma cultured cells, caspases were activated, causing an increase in cell apoptosis [160]. This suggests a role for miR-21 as a suppressor of apoptosis in this malignant tumor [160]. In chronic lymphocytic leukemias (CLL), the antiapoptotic protein B-cell lymphoma $2(\mathrm{Bcl} 2)$ is overexpressed [161]. Interestingly, frequent deletions and downregulation of the miR-15 and miR16 genes at the chromosome locus 13q14 are observed in the majority of CLLs [162]. These findings suggest a role for miR-15a and miR16-1 as repressors of Bcl2 expression and possible inducers of apoptosis [161].

\section{RELATIONSHIP BETWEEN MIRNAS AND DISEASES}

Given their recognized importance in gene regulation, a link between miRNAs and several major diseases is expected. For example, defects in miRNA-mediated regulation of mRNA translation may lead to overexpression of specific proteins, which accumulation may cause diseases. In fact, intriguing connections between miRNAs and diseases, such as cancer and viral infections, are emerging.

\section{miRNAs and cancer}

A recent study reported that human miRNA genes are frequently located at fragile sites and genomic regions involved in cancer [185]. Indeed, Calin et al [162] observed frequent deletions and downregulation of $m i R-15$ and $m i R-16$ genes at 13 q14 in CLL. These miRNAs have been shown to negatively regulate the antiapoptotic $\mathrm{Bcl} 2$ protein at the posttranscriptional level [161]. BCL2 repression by these miRNAs induced apoptopsis in a leukemic cell line model [161], thereby providing a link between the absence of miR-15/miR-16 and leukemia.

Northern blot analyses showed that miR-143 and miR145 expression is downregulated in various human cell lines derived from breast, prostate, cervical, lymphoid cancers, and, particularly, colorectal tumors [163]. Potential targets of these miRNAs have been previously implicated in oncogenesis [163].

A relationship between miRNAs and Burkitt lymphoma (BL) has been suggested. miR-155 is encoded within nucleotides 241-262 of the BIC gene, which is located on chromosome 21. Both the BIC and miR-155 genes are overexpressed in some BL patients, but not in all BL cases [164, 186]. Abnormal miRNA expression may thus contribute to the transformation of B cells [164].

Another miRNA cluster, miR-17-92, is often overexpressed in tumor samples from B-cell lymphomas when compared to normal cell lines [165]. This cluster is present in an amplified DNA region encoding for the ORF c13orf 25. Alignment of this ORF between mouse and human indicates that the polycistron and its immediate flanking sequences only are conserved. The c13orf25 transcript contains seven pre-miRNAs encoding for miR-17-5p, miR-173p, miR-18, miR-19a, miR-20, miR-19b-1, and miR-92-1. Using a microarray analysis of 191 mature miRNAs, five miRNAs from the cluster were found to be highly expressed in Bcell lymphomas, in correlation with an increased expression of c13orf 25 [165]. These studies revealed that the miR-17-92 cluster can act as a potential human oncogene, and was referred as oncomiR-1 by Hammond and colleagues [165].

Another group subsequently reported that the miR-1792 cluster was overexpressed in human lung cancer cell lines [187]. When analyzing the subcellular localization of the c13orf25 transcript, they observed a nuclear localization, restricting its cytoplasmic localization for translation. This suggested that this transcript can act as a vehicle for the expression of the miR-17-92 cluster. Its predicted targets include the tumor suppressor genes PTEN and RB2 [146]. In a mouse B-cell lymphoma model, the overexpression of miR17-92 accelerates tumor formation induced by the product of the MYC gene [165], which encodes an important transcription factor that regulates cell proliferation, growth, and apoptosis. Modification of MYC expression is a commonly observed deregulation leading to tumorigenesis. O'Donnell et al showed that c-myc, through binding to sequences near the miR-17-92 cluster genomic locus, activates miR-17-92 expression [188]. Among the predicted targets of the miR17-92 cluster is the transcription factor E2F1, which appears to be negatively regulated by miR-17-5p and miR-20a [146]. 
E2F1 is a cell cycle promoter induced upon c-myc expression. Conversely, c-myc expression is induced by E2F1 [189-191]. Therefore, a balance between the gene regulatory processes involving miRNAs and transcription factors may contribute to finely tune E2F1 expression and to generate a tightly controlled proliferative signal [188].

The let-7 miRNA also seems to be involved in cancer pathogenesis. Calin et al reported that let-7 genes are deleted in many cancers [185]. Moreover, a reduction in let-7 expression has been observed in samples of human lung cancers or cancer cell lines. Patients associated with a reduced let-7 expression had the worst prognosis after a potentially curative resection [192]. It is relevant to note that the overexpression of let-7 in lung cancer cells inhibits growth in vitro [192]. In C elegans, let-60, the ortholog of the human oncogene RAS, was found to contain eight putative let-7 binding sites in its $3^{\prime}$ NTR [156]. As for the three human RAS genes, they also contain multiple let-7 binding sites, allowing let-7 to regulate RAS expression. Evidences of a downregulatory role for let7 in RAS expression came from experiments using reporter genes fused to the $3^{\prime} \mathrm{NTR}$ of NRAS and KRAS [156]. Introduction of let-7a inhibitors relieved this repression [156]. In this study, miRNA microarray analyses of 21 different samples from lung cancer patients revealed that the expression of the let-7 gene family was reduced, in association with an increased expression of RAS protein. These data suggest a role for the let-7 miRNA family in the regulation of RAS during development of lung cancer [156].

Deregulated expression of protein components of the miRNA biosynthetic pathway may also be implicated in cancer formation. Karube et al [193] recently observed a diminution of Dicer expression in nonsmall cell lung cancer samples taken from 67 patients, as assessed by RT-PCR. As for the let-7 miRNA, this reduction was also associated with shorter postoperative survival [193]. Thus, the presence of Dicer, which mediates miRNA biogenesis, appears to be required for maintaining normal cell function.

miRNA expression profiling of the affected tissues may eventually be important for improving the diagnosis of diseases, such as cancer [194]. Using a new miRNA profiling method, Lu et al [195] analyzed mammalian miRNAs from 334 samples, including human cancers. They observed a characteristic general downregulation of miRNA expression in tumors, as compared to normal tissues [195]. Similarly, Jiang et al used an RT-PCR approach using primers specific to 222 pre-miRNAs to monitor their expression in human cancer cell lines [196]. Monitoring of global changes in miRNA expression profiles will be useful to establish possible links between miRNAs and diseases.

\section{miRNAs and viruses}

Several studies have reported a role for RNA silencing in host defense mechanisms against viruses in plants [197], and reports suggest that they may also play a similar role in humans. The interaction between RNA silencing pathways and viruses, such as HIV-1, is complex and multifaceted [198]. Some viral RNAs exhibit secondary structures that are prone to Dicer processing, as evidenced by the discovery of miRNAs derived from Epstein-Barr virus (EBV), a virus belonging to the herpesvirus family, in infected Burkitt's lymphoma cells [199]. In this case, miRNAs originate from five precursors present in two different clusters of the genome of EBV [199]. The overall impact of viral miRNAs on cellular and viral gene expression remains to be fully appreciated. They may target and regulate specific human mRNAs, thereby ultimately influencing cell function and viral replication. Indeed, the potential host mRNA targets of these miRNAs, as predicted by bioinformatical analyses, are implicated in many biological processes, such as transcription, cell proliferation, apoptosis, B cell-specific chemokine and cytokine synthesis, and signal transduction [199]. These findings illustrate how a virus may exploit the RNA silencing machinery for its own purpose.

miRNAs derived from a virus may also be turned against some of its mRNAs, as exemplified by miR-BART2. This EBV miRNA has been shown to be perfectly complementary to the EBV gene BALF5, encoding for a DNA polymerase, and to target it for degradation [199, 200].

The pathogenic human Kaposi's sarcoma-associated herpesvirus (KSHV) was recently shown to encode an array of 11 distinct miRNAs, all of which are expressed at readily detectable levels in latently KSHV infected cells [201]. Computer analysis of potential mRNA host targets for these viral miRNAs included several mRNAs previously shown to be downregulated in KSHV-infected cells, suggesting that KSHV miRNAs play a critical role in the establishment and/or maintenance of KSHV latent infection [201].

The genome of HIV-1 encodes a gene called nef, which is located in the $3^{\prime}$ region and is overlapping with the LTR. Omoto et al identified a nef-derived miRNA, called miRN367, produced in cells persistently infected with HIV-1. This miRNA has been shown to downregulate the transcription of the HIV-1 genome in human T cells by targeting the negative responsive element of its $5^{\prime} \mathrm{NTR} \mathrm{U} 3$ region and the nef sequence located in the $3^{\prime}$ NTR $[202,203]$. HIV-1 was also found to generate an siRNA that can mediate nucleicacid-based immunity and to encode a suppressor of RNA silencing in its Tat protein [204].

Additional evidences suggest that viruses have evolved to take advantage of RNA silencing pathways to enhance the probability of successful infection. For example, the simian virus 40 (SV40) genome was found to encode a pre-miRNA from which two miRNAs can be derived. Expressed at late times in infection, these miRNAs are perfectly complementary to the early viral mRNAs, and target those for degradation [205]. SV40-infected cells show a reduced expression of viral $\mathrm{T}$ antigens, are less sensitive to lysis by cytotoxic $\mathrm{T}$ cells, and trigger less cytokine production [205].

Cellular miRNAs may also play an important role in virus/host interactions. For example, miR-32 was found to restrict retrovirus primate foamy virus type 1 (PFV-1) accumulation in human cells [166]. However, PFV-1 may counteract this cellular restriction through expression of Tas, a protein inhibiting RNA silencing in mammalian cells [166]. Moreover, a study showed that the sequestration of miR122, an miRNA highly and specifically expressed in the liver, 
resulted in a marked loss of autonomously replicating hepatitis $\mathrm{C}$ virus (HCV) RNAs [167]. HCV replication thus appears to be facilitated by a genetic interaction between miR122 and the $5^{\prime}$ NTR of the HCV genome, making miR-122 a potential target for an anti-HCV intervention.

As for a possible regulation of HIV-1 replication by human miRNAs, computational predictions identified four possible HIV-1 targets: the nef gene targeted by miR-29a and miR-29b, the $v p r$ gene targeted by miR-149, the $v p u$ gene targeted by miR-378, and the vif gene targeted by miR-324-5p [168]. Microarray profiling confirmed the expression of these miRNAs in HIV-1 replication-competent human T lymphocytes [168]. Further investigation is required to determine the biological significance of these cellular miRNAs-HIV-1 interactions.

\section{CONCLUSION}

miRNAs are now recognized as key regulators of gene expression. Not surprisingly, causal links between deregulation of miRNA expression and some important genetic diseases are gradually emerging. A better characterization of the miRNA expression profiles observed in various clinical situations may ultimately be useful to physicians in providing signatures for specific tumors or infectious diseases. Further investigations that aim at elucidating and understanding the mechanisms involved in miRNA biosynthesis and function are crucial for the design and development of potentially important diagnostic tools and new therapeutic strategies.

\section{ACKNOWLEDGMENTS}

We are grateful to Gilles Chabot for graphic design. M. P. Perron and L.-A. Gobeil are supported by doctoral and master studentships from the Natural Sciences and Engineering Research Council of Canada (NSERC), respectively. P. Provost is a New Investigator of the Canadian Institutes of Health Research (CIHR) and The Arthritis Society. This work was supported by Discovery Grant 262938-03 from NSERC and Grant EOP-64706 from Health Canada/CIHR. D. L. Ouellet and M. P. Perron contributed equally to this work. P. Provost is the author for correspondence.

\section{REFERENCES}

[1] Napoli C, Lemieux C, Jorgensen R. Introduction of a chimeric chalcone synthase gene into petunia results in reversible co-suppression of homologous genes in trans. Plant Cell. 1990;2(4):279-289.

[2] Jorgensen R. Altered gene expression in plants due to trans interactions between homologous genes. Trends in Biotechnology. 1990;8(12):340-344.

[3] Lee RC, Feinbaum RL, Ambros V. The C. elegans heterochronic gene lin-4 encodes small RNAs with antisense complementarity to lin-14. Cell. 1993;75(5):843-854.

[4] Wightman B, Burglin TR, Gatto J, Arasu P, Ruvkun G. Negative regulatory sequences in the lin-14 3 '-untranslated region are necessary to generate a temporal switch during Caenorhabditis elegans development. Genes and Development. 1991;5(10):1813-1824.
[5] Wightman B, Ha I, Ruvkun G. Posttranscriptional regulation of the heterochronic gene lin-14 by lin- 4 mediates temporal pattern formation in C. elegans. Cell. 1993;75(5):855-862.

[6] Fire A, Xu S, Montgomery MK, Kostas SA, Driver SE, Mello CC. Potent and specific genetic interference by doublestranded RNA in Caenorhabditis elegans. Nature. 1998; 391(6669):806-811.

[7] Hamilton AJ, Baulcombe DC. A species of small antisense RNA in posttranscriptional gene silencing in plants. Science. 1999;286(5441):950-952.

[8] Zamore PD, Tuschl T, Sharp PA, Bartel DP. RNAi: doublestranded RNA directs the ATP-dependent cleavage of mRNA at 21 to 23 nucleotide intervals. Cell. 2000;101(1):25-33.

[9] Elbashir SM, Lendeckel W, Tuschl T. RNA interference is mediated by 21- and 22-nucleotide RNAs. Genes and Development. 2001;15(2):188-200.

[10] Lagos-Quintana M, Rauhut R, Lendeckel W, Tuschl T. Identification of novel genes coding for small expressed RNAs. Science. 2001;294(5543):853-858.

[11] Lau NC, Lim LP, Weinstein EG, Bartel DP. An abundant class of tiny RNAs with probable regulatory roles in Caenorhabditis elegans. Science. 2001;294(5543):858-862.

[12] Lee RC, Ambros V. An extensive class of small RNAs in Caenorhabditis elegans. Science. 2001;294(5543):862-864.

[13] Denli AM, Tops BBJ, Plasterk RHA, Ketting RF, Hannon GJ. Processing of primary microRNAs by the Microprocessor complex. Nature. 2004;432(7014):231-235.

[14] Gregory RI, Yan K-P, Amuthan G, et al. The Microprocessor complex mediates the genesis of microRNAs. Nature. 2004;432(7014):235-240.

[15] Han J, Lee Y, Yeom K-H, Kim Y-K, Jin H, Kim VN. The Drosha-DGCR8 complex in primary microRNA processing. Genes and Development. 2004;18(24):3016-3027.

[16] Landthaler M, Yalcin A, Tuschl T. The human DiGeorge syndrome critical region gene 8 and its D. melanogaster homolog are required for miRNA biogenesis. Current Biology. 2004;14(23):2162-2167.

[17] Cai X, Hagedorn CH, Cullen BR. Human microRNAs are processed from capped, polyadenylated transcripts that can also function as mRNAs. RNA. 2004;10(12):1957-1966.

[18] Lee Y, Ahn C, Han J, et al. The nuclear RNase III Drosha initiates microRNA processing. Nature. 2003;425(6956):415-419.

[19] Lee Y, Jeon K, Lee J-T, Kim S, Kim VN. MicroRNA maturation: stepwise processing and subcellular localization. EMBO Journal. 2002;21(17):4663-4670.

[20] Bohnsack MT, Czaplinski K, Görlich D. Exportin 5 is a RanGTP-dependent dsRNA-binding protein that mediates nuclear export of pre-miRNAs. RNA. 2004;10(2):185-191.

[21] Brownawell AM, Macara IG. Exportin-5, a novel karyopherin, mediates nuclear export of double-stranded RNA binding proteins. Journal of Cell Biology. 2002;156(1):53-64.

[22] Lund E, Güttinger S, Calado A, Dahlberg JE, Kutay U. Nuclear export of microRNA precursors. Science. 2004; 303(5654):95-98.

[23] Yi R, Qin Y, Macara IG, Cullen BR. Exportin-5 mediates the nuclear export of pre-microRNAs and short hairpin RNAs. Genes and Development. 2003;17(24):3011-3016.

[24] Gregory RI, Chendrimada TP, Cooch N, Shiekhattar R. Human RISC couples microRNA biogenesis and posttranscriptional gene silencing. Cell. 2005;123(4):631-640.

[25] Bartel DP. MicroRNAs: genomics, biogenesis, mechanism, and function. Cell. 2004;116(2):281-297. 
[26] Lee Y, Kim M, Han J, et al. MicroRNA genes are transcribed by RNA polymerase II. EMBO Journal. 2004;23(20):40514060.

[27] Rodriguez A, Griffiths-Jones S, Ashurst JL, Bradley A. Identification of mammalian microRNA host genes and transcription units. Genome Research. 2004;14(10A):1902-1910.

[28] Ying S-Y, Lin S-L. Intronic microRNAs. Biochemical and Biophysical Research Communications. 2005;326(3):515-520.

[29] Lagos-Quintana M, Rauhut R, Meyer J, Borkhardt A, Tuschl T. New microRNAs from mouse and human. RNA. 2003; 9(2):175-179.

[30] Wu H, Xu H, Miraglia LJ, Crooke ST. Human RNase III is a $160-\mathrm{kDa}$ protein involved in preribosomal RNA processing. Journal of Biological Chemistry. 2000;275(47):36957-36965.

[31] Filippov V, Solovyev V, Filippova M, Gill SS. A novel type of RNase III family proteins in eukaryotes. Gene. 2000;245(1): 213-221.

[32] Fortin KR, Nicholson RH, Nicholson AW. Mouse ribonuclease III. cDNA structure, expression analysis, and chromosomal location. BMC Genomics. 2002;3(1):26.

[33] Basyuk E, Suavet F, Doglio A, Bordonné R, Bertrand E. Human let-7 stem-loop precursors harbor features of RNase III cleavage products. Nucleic Acids Research. 2003;31(22):65936597.

[34] Zeng Y, Cullen BR. Sequence requirements for micro RNA processing and function in human cells. RNA. 2003; 9(1):112-123.

[35] Zhang H, Kolb FA, Jaskiewicz L, Westhof E, Filipowicz W. Single processing center models for human Dicer and bacterial RNase III. Cell. 2004;118(1):57-68.

[36] Arvand A, Denny CT. Biology of EWS/ETS fusions in Ewing's family tumors. Oncogene. 2001;20(40):5747-5754.

[37] Yamagishi H, Srivastava D. Unraveling the genetic and developmental mysteries of 22q11 deletion syndrome. Trends in Molecular Medicine. 2003;9(9):383-389.

[38] Shiohama A, Sasaki T, Noda S, Minoshima S, Shimizu N. Molecular cloning and expression analysis of a novel gene DGCR8 located in the DiGeorge syndrome chromosomal region. Biochemical and Biophysical Research Communications. 2003;304(1):184-190.

[39] Yi R, Doehle BP, Qin Y, Macara IG, Cullen BR. Overexpression of Exportin 5 enhances RNA interference mediated by short hairpin RNAs and microRNAs. RNA. 2005;11(2):220226.

[40] Zeng Y, Cullen BR. Structural requirements for premicroRNA binding and nuclear export by Exportin 5. Nucleic Acids Research. 2004;32(16):4776-4785.

[41] Gwizdek C, Ossareh-Nazari B, Brownawell AM, et al. Exportin-5 mediates nuclear export of minihelix-containing RNAs. Journal of Biological Chemistry. 2003;278(8):55055508.

[42] Bernstein E, Caudy AA, Hammond SM, Hannon GJ. Role for a bidentate ribonuclease in the initiation step of RNA interference. Nature. 2001;409(6818):363-366.

[43] Grishok A, Pasquinelli AE, Conte D, et al. Genes and mechanisms related to RNA interference regulate expression of the small temporal RNAs that control C. elegans developmental timing. Cell. 2001;106(1):23-34.

[44] Knight SW, Bass BL. A role for the RNase III enzyme DCR-1 in RNA interference and germ line development in Caenorhabditis elegans. Science. 2001;293(5538):2269-2271.

[45] Hutvágner G, McLachlan J, Pasquinelli AE, Bálint É, Tuschl T, Zamore PD. A cellular function for the RNA-interference enzyme dicer in the maturation of the let-7 small temporal RNA. Science. 2001;293(5531):834-838.

[46] Provost P, Samuelsson B, Radmark O. Interaction of 5lipoxygenase with cellular proteins. Proceedings of the $\mathrm{Na}$ tional Academy of Sciences of the United States of America. 1999;96(5):1881-1885.

[47] Provost P, Dishart D, Doucet J, Frendewey D, Samuelsson B, Radmark O. Ribonuclease activity and RNA binding of recombinant human Dicer. EMBO Journal. 2002;21(21):58645874.

[48] Zhang H, Kolb FA, Brondani V, Billy E, Filipowicz W. Human Dicer preferentially cleaves dsRNAs at their termini without a requirement for ATP. EMBO Journal. 2002;21(21):58755885.

[49] Billy E, Brondani V, Zhang H, Müller U, Filipowicz W. Specific interference with gene expression induced by long, double-stranded RNA in mouse embryonal teratocarcinoma cell lines. Proceedings of the National Academy of Sciences of the United States of America. 2001;98(25):14428-14433.

[50] Bernstein E, Kim SY, Carmell MA, et al. Dicer is essential for mouse development. Nature Genetics. 2003;35(3):215-217.

[51] Yang WJ, Yang DD, Na S, Sandusky GE, Zhang Q, Zhao G. Dicer is required for embryonic angiogenesis during mouse development. Journal of Biological Chemistry. 2005;280(10): 9330-9335.

[52] Kanellopoulou C, Muljo SA, Kung AL, et al. Dicer-deficient mouse embryonic stem cells are defective in differentiation and centromeric silencing. Genes and Development. 2005; 19(4):489-501.

[53] Murchison EP, Partridge JF, Tam OH, Cheloufi S, Hannon GJ. Characterization of Dicer-deficient murine embryonic stem cells. Proceedings of the National Academy of Sciences of the United States of America. 2005;102(34):12135-12140.

[54] Hammond SM, Boettcher S, Caudy AA, Kobayashi R, Hannon GJ. Argonaute2, a link between genetic and biochemical analyses of RNAi. Science. 2001;293(5532):1146-1150.

[55] Ishizuka A, Siomi MC, Siomi H. A Drosophila fragile X protein interacts with components of RNAi and ribosomal proteins. Genes and Development. 2002;16(19):2497-2508.

[56] Chendrimada TP, Gregory RI, Kumaraswamy E, et al. TRBP recruits the Dicer complex to Ago 2 for microRNA processing and gene silencing. Nature. 2005;436(7051):740-744.

[57] Haase AD, Jaskiewicz L, Zhang H, et al. TRBP, a regulator of cellular PKR and HIV-1 virus expression, interacts with Dicer and functions in RNA silencing. EMBO Reports. 2005;6(10):961-967.

[58] Lee Y, Hur I, Park S-Y, Kim Y-K, Suh MR, Kim VN. The role of PACT in the RNA silencing pathway. EMBO Journal. 2006;25(3):522-532.

[59] Gatignol A, Buckler-White A, Berkhout B, Jeang K-T. Characterization of a human TAR RNA-binding protein that activates the HIV-1 LTR. Science. 1991;251(5001):1597-1600.

[60] Duarte M, Graham K, Daher A, et al. Characterization of TRBP1 and TRBP2: stable stem-loop structure at the $5^{\prime}$ end of TRBP2 mRNA resembles HIV-1 TAR and is not found in its processed pseudogene. Journal of Biomedical Science. 2000;7(6):494-506.

[61] Daher A, Longuet M, Dorin D, et al. Two dimerization domains in the trans-activation response RNA-binding protein (TRBP) individually reverse the protein kinase $\mathrm{R}$ inhibition of HIV-1 long terminal repeat expression. Journal of Biological Chemistry. 2001;276(36):33899-33905.

[62] Gatignol A, Duarte M, Daviet L, Chang Y-N, Jeang K-T. Sequential steps in Tat trans-activation of HIV-1 mediated 
through cellular DNA, RNA, and protein binding factors. Gene Expression. 1996;5(4-5):217-228.

[63] Donzeau M, Winnacker E-L, Meisterernst M. Specific repression of Tax trans-activation by TAR RNA-binding protein TRBP. Journal of Virology. 1997;71(4):2628-2635.

[64] Park H, Davies MV, Langland JO, et al. TAR RNA-binding protein is an inhibitor of the interferon-induced protein kinase PKR. Proceedings of the National Academy of Sciences of the United States of America. 1994;91(11):4713-4717.

[65] Förstemann K, Tomari Y, Du T, et al. Normal microRNA maturation and germ-line stem cell maintenance requires Loquacious, a double-stranded RNA-binding domain protein. PLoS Biology. 2005;3(7):e236.

[66] Saito K, Ishizuka A, Siomi H, Siomi MC. Processing of pre-microRNAs by the Dicer-1-Loquacious complex in Drosophila cells. PLoS Biology. 2005;3(7):e235.

[67] Liu Q, Rand TA, Kalidas S, et al. R2D2, a bridge between the initiation and effector steps of the Drosophila RNAi pathway. Science. 2003;301(5641):1921-1925.

[68] Grishok A, Tabara H, Mello CC. Genetic requirements for inheritance of RNAi in C. elegans. Science. 2000;287(5462): 2494-2497.

[69] Tabara H, Yigit E, Siomi H, Mello CC. The dsRNA binding protein RDE-4 interacts with RDE-1, DCR-1, and a DExHbox helicase to direct RNAi in C. elegans. Cell. 2002;109(7): 861-871.

[70] Schwarz DS, Hutvágner G, Du T, Xu Z, Aronin N, Zamore PD. Asymmetry in the assembly of the RNAi enzyme complex. Cell. 2003;115(2):199-208.

[71] Tomari Y, Matranga C, Haley B, Martinez N, Zamore PD. A protein sensor for siRNA asymmetry. Science. 2004; 306(5700):1377-1380.

[72] Pellino JL, Sontheimer EJ. R2D2 leads the silencing trigger to mRNA's death star. Cell. 2003;115(2):132-133.

[73] Lim LP, Lau NC, Garrett-Engele P, et al. Microarray analysis shows that some microRNAs downregulate large numbers of target mRNAs. Nature. 2005;433(7027):769-773.

[74] Yekta S, Shih I-H, Bartel DP. MicroRNA-directed cleavage of HOXB8 mRNA. Science. 2004;304(5670):594-596.

[75] Bagga S, Bracht J, Hunter S, et al. Regulation by let-7 and lin4 miRNAs results in target mRNA degradation. Cell. 2005; 122(4):553-563.

[76] Hammond SM, Bernstein E, Beach D, Hannon GJ. An RNAdirected nuclease mediates post-transcriptional gene silencing in Drosophila cells. Nature. 2000;404(6775):293-296.

[77] Nykänen A, Haley B, Zamore PD. ATP requirements and small interfering RNA structure in the RNA interference pathway. Cell. 2001;107(3):309-321.

[78] Pham JW, Pellino JL, Lee YS, Carthew RW, Sontheimer EJ. A Dicer-2-dependent $80 \mathrm{~S}$ complex cleaves targeted mRNAs during RNAi in Drosophila. Cell. 2004;117(1):83-94.

[79] Matranga C, Tomari Y, Shin C, Bartel DP, Zamore PD. Passenger-strand cleavage facilitates assembly of siRNA into Ago2-containing RNAi enzyme complexes. Cell. 2005; 123(4):607-620.

[80] Rand TA, Petersen S, Du F, Wang X. Argonaute2 cleaves the anti-guide strand of siRNA during RISC activation. Cell. 2005;123(4):621-629.

[81] Mourelatos Z, Dostie J, Paushkin S, et al. miRNPs: a novel class of ribonucleoproteins containing numerous microRNAs. Genes and Development. 2002;16(6):720-728.

[82] Liu J, Valencia-Sanchez MA, Hannon GJ, Parker R. MicroRNA-dependent localization of targeted mRNAs to mammalian P-bodies. Nature Cell Biology. 2005;7(7):719-723.
[83] Teixeira D, Sheth U, Valencia-Sanchez MA, Brengues M, Parker R. Processing bodies require RNA for assembly and contain nontranslating mRNAs. RNA. 2005;11(4):371-382.

[84] Eystathioy T, Chan EKL, Tenenbaum SA, Keene JD, Griffith K, Fritzler MJ. A phosphorylated cytoplasmic autoantigen, GW182, associates with a unique population of human mRNAs within novel cytoplasmic speckles. Molecular Biology of the Cell. 2002;13(4):1338-1351.

[85] Eystathioy T, Jakymiw A, Chan EKL, Séraphin B, Cougot N, Fritzler MJ. The GW182 protein colocalizes with mRNA degradation associated proteins hDcp 1 and hLSm4 in cytoplasmic GW bodies. RNA. 2003;9(10):1171-1173.

[86] Liu J, Rivas FV, Wohlschlegel J, Yates JR III, Parker R, Hannon GJ. A role for the P-body component GW182 in microRNA function. Nature Cell Biology. 2005;7(12):1161-1166.

[87] Jakymiw A, Lian S, Eystathioy T, et al. Disruption of GW bodies impairs mammalian RNA interference. Nature Cell Biology. 2005;7(12):1167-1174.

[88] Robb GB, Brown KM, Khurana J, Rana TM. Specific and potent RNAi in the nucleus of human cells. Nature Structural and Molecular Biology. 2005;12(2):133-137.

[89] Langlois M-A, Boniface C, Wang G, et al. Cytoplasmic and nuclear retained DMPK mRNAs are targets for RNA interference in myotonic dystrophy cells. Journal of Biological Chemistry. 2005;280(17):16949-16954.

[90] Volpe TA, Kidner C, Hall IM, Teng G, Grewal SIS, Martienssen RA. Regulation of heterochromatic silencing and histone H3 lysine-9 methylation by RNAi. Science. 2002; 297(5588):1833-1837.

[91] Kataoka Y, Takeichi M, Uemura T. Developmental roles and molecular characterization of a Drosophila homologue of Arabidopsis Argonaute1, the founder of a novel gene superfamily. Genes to Cells. 2001;6(4):313-325.

[92] Cerutti L, Mian N, Bateman A. Domains in gene silencing and cell differentiation proteins: the novel PAZ domain and redefinition of the Piwi domain. Trends in Biochemical Sciences. 2000;25(10):481-482.

[93] Sasaki T, Shiohama A, Minoshima S, Shimizu N. Identification of eight members of the Argonaute family in the human genome small star, filled. Genomics. 2003;82(3):323-330.

[94] Meister G, Landthaler M, Patkaniowska A, Dorsett Y, Teng G, Tuschl T. Human Argonaute2 mediates RNA cleavage targeted by miRNAs and siRNAs. Molecular Cell. 2004;15(2): 185-197.

[95] Liu J, Carmell MA, Rivas FV, et al. Argonaute2 is the catalytic engine of mammalian RNAi. Science. 2004;305(5689):14371441.

[96] Verdel A, Jia S, Gerber S, et al. RNAi-mediated targeting of heterochromatin by the RITS complex. Science. 2004; 303(5658):672-676.

[97] Carmell MA, Xuan Z, Zhang MQ, Hannon GJ. The Argonaute family: tentacles that reach into RNAi, developmental control, stem cell maintenance, and tumorigenesis. Genes and Development. 2002;16(21):2733-2742.

[98] Yan KS, Yan S, Farooq A, Han A, Zeng L, Zhou M-M. Structure and conserved RNA binding of the PAZ domain. Nature. 2003;426(6965):468-474.

[99] Lingel A, Simon B, Izaurralde E, Sattler M. Nucleic acid 3 '-end recognition by the Argonaute2 PAZ domain. Nature Structural and Molecular Biology. 2004;11(6):576-577.

[100] Song J-J, Liu J, Tolia NH, et al. The crystal structure of the Argonaute2 PAZ domain reveals an RNA binding motif in 
RNAi effector complexes. Nature Structural Biology. 2003; 10(12):1026-1032.

[101] Lingel A, Simon B, Izaurralde E, Sattler M. Structure and nucleic-acid binding of the Drosophila Argonaute 2 PAZ domain. Nature. 2003;426(6965):465-469.

[102] Song J-J, Smith SK, Hannon GJ, Joshua-Tor L. Crystal structure of Argonaute and its implications for RISC slicer activity. Science. 2004;305(5689):1434-1437.

[103] Parker JS, Roe SM, Barford D. Crystal structure of a PIWI protein suggests mechanisms for siRNA recognition and slicer activity. EMBO Journal. 2004;23(24):4727-4737.

[104] Ma J-B, Yuan Y-R, Meister G, Pei Y, Tuschl T, Patel DJ. Structural basis for $5^{\prime}$-end-specific recognition of guide RNA by the A. fulgidus Piwi protein. Nature. 2005;434(7033):666670.

[105] Parker JS, Roe SM, Barford D. Structural insights into mRNA recognition from a PIWI domain-siRNA guide complex. $\mathrm{Na}$ ture. 2005;434(7033):663-666.

[106] Schwarz DS, Tomari Y, Zamore PD. The RNA-induced silencing complex is a $\mathrm{Mg}^{2+}$-dependent endonuclease. Current Biology. 2004;14(9):787-791.

[107] Mahillon J, Chandler M. Insertion sequences. Microbiology and Molecular Biology Reviews. 1998;62(3):725-774.

[108] Rivas FV, Tolia NH, Song J-J, et al. Purified Argonaute2 and an siRNA form recombinant human RISC. Nature Structural and Molecular Biology. 2005;12(4):340-349.

[109] Elbashir SM, Martinez J, Patkaniowska A, Lendeckel W, Tuschl T. Functional anatomy of siRNAs for mediating efficient RNAi in Drosophila melanogaster embryo lysate. EMBO Journal. 2001;20(23):6877-6888.

[110] Pillai RS, Artus CG, Filipowicz W. Tethering of human Ago proteins to mRNA mimics the miRNA-mediated repression of protein synthesis. RNA. 2004;10(10):1518-1525.

[111] Pillai RS, Bhattacharyya SN, Artus CG, et al. Inhibition of translational initiation by let-7 MicroRNA in human cells. Science. 2005;309(5740):1573-1576.

[112] O'Donnell WT, Warren ST. A decade of molecular studies of fragile X syndrome. Annual Review of Neuroscience. 2002;25:315-338.

[113] Bardoni B, Mandel J-L. Advances in understanding of fragile $\mathrm{X}$ pathogenesis and FMRP function, and in identification of $\mathrm{X}$ linked mental retardation genes. Current Opinion in Genetics and Development. 2002;12(3):284-293.

[114] Siomi H, Siomi MC, Nussbaum RL, Dreyfuss G. The protein product of the fragile X gene, FMR1, has characteristics of an RNA-binding protein. Cell. 1993;74(2):291-298.

[115] Verhelj C, Bakker CE, de Graaff E, et al. Characterization and localization of the FMR-1 gene product associated with fragile X syndrome. Nature. 1993;363(6431):722-724.

[116] Laggerbauer B, Ostareck D, Keidel E-M, Ostareck-Lederer A, Fischer U. Evidence that fragile X mental retardation protein is a negative regulator of translation. Human Molecular Genetics. 2001;10(4):329-338.

[117] Li Z, Zhang Y, Ku L, Wilkinson KD, Warren ST, Feng Y. The fragile $\mathrm{X}$ mental retardation protein inhibits translation via interacting with mRNA. Nucleic Acids Research. 2001;29(11):2276-2283.

[118] Mazroui R, Hout ME, Tremblay S, Fillion C, Labelle Y, Khandjian EW. Trapping of messenger RNA by Fragile X Mental Retardation protein into cytoplasmic granules induces translation repression. Human Molecular Genetics. 2002;11(24):3007-3017.
[119] Caudy AA, Myers M, Hannon GJ, Hammond SM. Fragile Xrelated protein and VIG associate with the RNA interference machinery. Genes and Development. 2002;16(19):2491-2496.

[120] Jin P, Zarnescu DC, Ceman S, et al. Biochemical and genetic interaction between the fragile $\mathrm{X}$ mental retardation protein and the microRNA pathway. Nature Neuroscience. 2004;7(2):113-117.

[121] Plante I, Davidovic L, Ouellet DL, et al. Dicer-derived microRNAs are utilized by the fragile $\mathrm{X}$ mental retardation protein for assembly on target RNAs. Journal of Biomedicine and Biotechnology. In press.

[122] Heaton JH, Dlakic WM, Dlakic M, Gelehrter TD. Identification and cDNA cloning of a novel RNA-binding protein that Interacts with the cyclic nucleotide-responsive sequence in the Type-1 plasminogen activator inhibitor mRNA. Journal of Biological Chemistry. 2001;276(5):3341-3347.

[123] Jing Q, Huang S, Guth S, et al. Involvement of microRNA in AU-rich element-mediated mRNA instability. Cell. 2005;120(5):623-634.

[124] Caudy AA, Ketting RF, Hammond SM, et al. A micrococcal nuclease homologue in RNAi effector complexes. Nature. 2003;425(6956):411-414.

[125] Martinez J, Tuschl T. RISC is a $5^{\prime}$ phosphomonoesterproducing RNA endonuclease. Genes and Development. 2004; 18(9):975-980.

[126] Reddi KK. Mode of action of micrococcal phosphodiesterase. Nature. 1960;187:74-75.

[127] Bass BL. RNA editing by adenosine deaminases that act on RNA. Annual Review of Biochemistry. 2002;71:817-846.

[128] Scadden ADJ. The RISC subunit Tudor-SN binds to hyperedited double-stranded RNA and promotes its cleavage. $\mathrm{Na}$ ture Structural and Molecular Biology. 2005;12(6):489-496.

[129] Yang W, Chendrimada TP, Wang Q, et al. Modulation of microRNA processing and expression through RNA editing by ADAR deaminases. Nature Structural and Molecular Biology. 2006;13(1):13-21.

[130] Luciano DJ, Mirsky H, Vendetti NJ, Maas S. RNA editing of a miRNA precursor. RNA. 2004;10(8):1174-1177.

[131] Knight SW, Bass BL. The role of RNA editing by ADARs in RNAi. Molecular Cell. 2002;10(4):809-817.

[132] Scadden ADJ, Smith CWJ. RNAi is antagonized by $\mathrm{A} \rightarrow \mathrm{I}$ hyper-editing. EMBO Reports. 2001;2(12):1107-1111.

[133] Scadden ADJ, O'Connell MA. Cleavage of dsRNAs hyperedited by ADARs occurs at preferred editing sites. Nucleic Acids Research. 2005;33(18):5954-5964.

[134] Provost P, Silverstein RA, Dishart D, et al. Dicer is required for chromosome segregation and gene silencing in fission yeast cells. Proceedings of the National Academy of Sciences of the United States of America. 2002;99(26):16648-16653.

[135] Reinhart BJ, Bartel DP. Small RNAs correspond to centromere heterochromatic repeats. Science. 2002;297(5588): 1831.

[136] Noma KI, Sugiyama T, Cam H, et al. RITS acts in cis to promote RNA interference-mediated transcriptional and posttranscriptional silencing. Nature Genetics. 2004;36(11):11741180.

[137] Petrie VJ, Wuitschick JD, Givens CD, Kosinski AM, Partridge JF. RNA interference (RNAi)-dependent and RNAiindependent association of the Chpl chromodomain protein with distinct heterochromatic loci in fission yeast. Molecular and Cellular Biology. 2005;25(6):2331-2346.

[138] Ekwall K, Nimmo ER, Javerzat JP, et al. Mutations in the fission yeast silencing factors clr4+ and rik1+ disrupt the localisation of the chromo domain protein Swi6p and impair cen- 
tromere function. Journal of Cell Science. 1996;109(11):26372648.

[139] Ambros V, Bartel B, Bartel DP, et al. A uniform system for microRNA annotation. RNA. 2003;9(3):277-279.

[140] Ohler U, Yekta S, Lim LP, Bartel DP, Burge CB. Patterns of flanking sequence conservation and a characteristic upstream motif for microRNA gene identification. RNA. 2004;10(9): $1309-1322$.

[141] Griffiths-Jones S, Grocock RJ, van Dongen S, Bateman A, Enright AJ. miRBase: microRNA sequences, targets and gene nomenclature. Nucleic Acids Research. 2006;34:D140-D144.

[142] Griffiths-Jones S. The microRNA Registry. Nucleic Acids Research. 2004;32:D109-D111.

[143] Vella MC, Reinert K, Slack FJ. Architecture of a validated microRNA: target interaction. Chemistry and Biology. 2004; 11(12):1619-1623.

[144] Lewis BP, Burge CB, Bartel DP. Conserved seed pairing, often flanked by adenosines, indicates that thousands of human genes are microRNA targets. Cell. 2005;120(1):15-20.

[145] Xie X, Lu J, Kulbokas EJ, et al. Systematic discovery of regulatory motifs in human promoters and 3' UTRs by comparison of several mammals. Nature. 2005;434(7031):338-345.

[146] Lewis BP, Shih IH, Jones-Rhoades MW, Bartel DP, Burge CB. Prediction of mammalian microRNA targets. Cell. 2003;115(7):787-798.

[147] John B, Enright AJ, Aravin A, Tuschl T, Sander C, Marks DS. Human microRNA targets. PLoS Biology. 2004;2(11):e363.

[148] Kiriakidou M, Nelson PT, Kouranov A, et al. A combined computational-experimental approach predicts human microRNA targets. Genes and Development. 2004;18(10):11651178.

[149] Vella MC, Choi EY, Lin SY, Reinert K, Slack FJ. The C. elegans microRNA let-7 binds to imperfect let-7 complementary sites from the lin-41 3'UTR. Genes and Development. 2004;18(2):132-137.

[150] Chen CZ, Li L, Lodish HF, Bartel DP. MicroRNAs modulate hematopoietic lineage differentiation. Science. 2004; 303(5654):83-86.

[151] Moss EG, Lee RC, Ambros V. The cold shock domain protein LIN-28 controls developmental timing in C. elegans and is regulated by the lin-4 RNA. Cell. 1997;88(5):637-646.

[152] Reinhart BJ, Slack FJ, Basson M, et al. The 21-nucleotide let-7 RNA regulates developmental timing in Caenorhabditis elegans. Nature. 2000;403(6772):901-906.

[153] Pasquinelli AE, Reinhart BJ, Slack FJ, et al. Conservation of the sequence and temporal expression of let-7 heterochronic regulatory RNA. Nature. 2000;408(6808):86-89.

[154] Slack FJ, Basson M, Liu Z, Ambros V, Horvitz HR, Ruvkun G. The lin-41 RBCC gene acts in the C. elegans heterochronic pathway between the let-7 regulatory RNA and the LIN-29 transcription factor. Molecular Cell. 2000;5(4):659-669.

[155] Großhans H, Johnson T, Reinert KL, Gerstein M, Slack FJ. The temporal patterning microRNA let-7 regulates several transcription factors at the larval to adult transition in C. elegans. Developmental Cell. 2005;8(3):321-330.

[156] Johnson SM, Grosshans H, Shingara J, et al. RAS is regulated by the let-7 microRNA family. Cell. 2005;120(5):635-647.

[157] Abbott AL, Alvarez-Saavedra E, Miska EA, et al. The let7 MicroRNA family members mir-48, mir-84, and mir241 function together to regulate developmental timing in Caenorhabditis elegans. Developmental Cell. 2005;9(3):403414.

[158] Hipfner DR, Weigmann K, Cohen SM. The bantam gene regulates Drosophila growth. Genetics. 2002;161(4):1527-1537.
[159] Leaman D, Chen PY, Fak J, et al. Antisense-mediated depletion reveals essential and specific functions of microRNAs in Drosophila development. Cell. 2005;121(7):1097-1108.

[160] Chan JA, Krichevsky AM, Kosik KS. MicroRNA-21 is an antiapoptotic factor in human glioblastoma cells. Cancer Research. 2005;65(14):6029-6033.

[161] Cimmino A, Calin GA, Fabbri M, et al. miR-15 and miR-16 induce apoptosis by targeting BCL2. Proceedings of the $\mathrm{Na}$ tional Academy of Sciences of the United States of America. 2005;102(39):13944-13949.

[162] Calin GA, Dumitru CD, Shimizu M, et al. Frequent deletions and down-regulation of micro-RNA genes miR15 and miR16 at 13 q14 in chronic lymphocytic leukemia. Proceedings of the National Academy of Sciences of the United States of America. 2002;99(24):15524-15529.

[163] Michael MZ, O’Connor SM, van Holst Pellekaan NG, Young GP, James RJ. Reduced accumulation of specific microRNAs in colorectal neoplasia. Molecular Cancer Research. 2003;1(12):882-891.

[164] Metzler M, Wilda M, Busch K, Viehmann S, Borkhardt A. High expression of precursor microRNA-155/BIC RNA in children with Burkitt lymphoma. Genes Chromosomes and Cancer. 2004;39(2):167-169.

[165] He L, Thomson JM, Hemann MT, et al. A microRNA polycistron as a potential human oncogene. Nature. 2005; 435(7043):828-833.

[166] Lecellier C-H, Dunoyer P, Arar K, et al. A cellular microRNA mediates antiviral defense in human cells. Science. 2005; 308(5721):557-560.

[167] Jopling CL, Yi M, Lancaster AM, Lemon SM, Sarnow P. Modulation of hepatitis $\mathrm{C}$ virus RNA abundance by a liver-specific MicroRNA. Science. 2005;309(5740):1577-1581.

[168] Hariharan M, Scaria V, Pillai B, Brahmachari SK. Targets for human encoded microRNAs in HIV genes. Biochemical and Biophysical Research Communications. 2005;337(4):12141218.

[169] Boehm M, Slack FJ. A developmental timing microRNA and its target regulate life span in C. elegans. Science. 2005; 310(5756):1954-1957.

[170] Lim LP, Glasner ME, Yekta S, Burge CB, Bartel DP. Vertebrate microRNA genes. Science. 2003;299(5612):1540.

[171] Kloosterman WP, Wienholds E, Ketting RF, Plasterk RHA. Substrate requirements for let-7 function in the developing zebrafish embryo. Nucleic Acids Research. 2004;32(21):62846291.

[172] Giraldez AJ, Cinalli RM, Glasner ME, et al. MicroRNAs regulate brain morphogenesis in zebrafish. Science. 2005; 308(5723):833-838.

[173] Wienholds E, Kloosterman WP, Miska E, et al. MicroRNA expression in zebrafish embryonic development. Science. 2005;309(5732):310-311.

[174] Aboobaker AA, Tomancak P, Patel N, Rubin GM, Lai EC. Drosophila microRNAs exhibit diverse spatial expression patterns during embryonic development. Proceedings of the National Academy of Sciences of the United States of America. 2005;102(50):18017-18022.

[175] Lancman JJ, Caruccio NC, Harfe BD, et al. Analysis of the regulation of lin-41 during chick and mouse limb development. Developmental Dynamics. 2005;234(4):948-960.

[176] Schulman BRM, Esquela-Kerscher A, Slack FJ. Reciprocal expression of lin-41 and the microRNAs let-7 and mir125 during mouse embryogenesis. Developmental Dynamics. 2005;234(4):1046-1054. 
[177] Harfe BD, McManus MT, Mansfield JH, Hornstein E, Tabin CJ. The RNaseIII enzyme Dicer is required for morphogenesis but not patterning of the vertebrate limb. Proceedings of the National Academy of Sciences of the United States of America. 2005;102(31):10898-10903.

[178] Mochizuki K, Fine NA, Fujisawa T, Gorovsky MA. Analysis of a piwi-related gene implicates small RNAs in genome rearrangement in tetrahymena. Cell. 2002;110(6):689-699.

[179] Volpe T, Schramke V, Hamilton GL, et al. RNA interference is required for normal centromere function in fission yeast. Chromosome Research. 2003;11(2):137-146.

[180] Ekwall K. The roles of histone modifications and small RNA in centromere function. Chromosome Research. 2004;12(6): 535-542.

[181] Morris KV, Chan SW-L, Jacobsen SE, Looney DJ. Small interfering RNA-induced transcriptional gene silencing in human cells. Science. 2004;305(5688):1289-1292.

[182] Kawasaki H, Taira K. Induction of DNA methylation and gene silencing by short interfering RNAs in human cells. $\mathrm{Na}$ ture. 2004;431(7005):211-217.

[183] Brennecke J, Hipfner DR, Stark A, Russell RB, Cohen SM. bantam encodes a developmentally regulated microRNA that controls cell proliferation and regulates the proapoptotic gene hid in Drosophila. Cell. 2003;113(1):25-36.

[184] Cheng AM, Byrom MW, Shelton J, Ford LP. Antisense inhibition of human miRNAs and indications for an involvement of miRNA in cell growth and apoptosis. Nucleic Acids Research. 2005;33(4):1290-1297.

[185] Calin GA, Sevignani C, Dumitru CD, et al. Human microRNA genes are frequently located at fragile sites and genomic regions involved in cancers. Proceedings of the $\mathrm{Na}$ tional Academy of Sciences of the United States of America. 2004;101(9):2999-3004.

[186] Kluiver J, Haralambieva E, de Jong D, et al. Lack of BIC and microRNA miR-155 expression in primary cases of Burkitt lymphoma. Genes Chromosomes and Cancer. 2006;45(2): 147-153.

[187] Hayashita Y, Osada H, Tatematsu Y, et al. A polycistronic microRNA cluster, miR-17-92, is overexpressed in human lung cancers and enhances cell proliferation. Cancer Research. 2005;65(21):9628-9632.

[188] O’Donnell KA, Wentzel EA, Zeller KI, Dang CV, Mendell JT. c-Myc-regulated microRNAs modulate E2F1 expression. $\mathrm{Na}$ ture. 2005;435(7043):839-843.

[189] Bracken AP, Ciro M, Cocito A, Helin K. E2F target genes: unraveling the biology. Trends in Biochemical Sciences. 2004; 29(8):409-417.

[190] Leone G, DeGregori J, Sears R, Jakoi L, Nevins JR. Myc and Ras collaborate in inducing accumulation of active cyclin E/Cdk2 and E2F. Nature. 1997;387(6631):422-426.

[191] Fernandez PC, Frank SR, Wang L, et al. Genomic targets of the human c-Myc protein. Genes and Development. 2003; 17(9):1115-1129.

[192] Takamizawa J, Konishi H, Yanagisawa K, et al. Reduced expression of the let-7 microRNAs in human lung cancers in association with shortened postoperative survival. Cancer Research. 2004;64(11):3753-3756.

[193] Karube Y, Tanaka H, Osada H, et al. Reduced expression of Dicer associated with poor prognosis in lung cancer patients. Cancer Science. 2005;96(2):111-115.

[194] Perron MP, Boissonneault V, Gobeil L-A, Ouellet DL, Provost P. Regulatory RNAs: future perspectives in diagnosis and personalized therapy. In: Stoud M, ed. Methods in Molecular
Biology: Target Discovery and Validation. Totowa, NJ: The Humana Press.

[195] Lu J, Getz G, Miska EA, et al. MicroRNA expression profiles classify human cancers. Nature. 2005;435(7043):834-838.

[196] Jiang J, Lee EJ, Gusev Y, Schmittgen TD. Real-time expression profiling of microRNA precursors in human cancer cell lines. Nucleic Acids Research. 2005;33(17):5394-5403.

[197] Baulcombe D. RNA silencing in plants. Nature. 2004; 431(7006):356-363.

[198] Provost P, Barat C, Plante I, Tremblay MJ. Human immunodeficiency virus-1 and RNA silencing pathways: a close and multifaceted encounter. In: Stoud M, ed. Methods in Molecular Biology: Target Discovery and Validation. Totowa, NJ: The Humana Press.

[199] Pfeffer S, Zavolan M, Grässer FA, et al. Identification of virusencoded microRNAs. Science. 2004;304(5671):734-736.

[200] Enright AJ, John B, Gaul U, Tuschl T, Sander C, Marks DS. MicroRNA targets in Drosophila. Genome Biology. 2003; 5(1):R1.

[201] Cai X, Lu S, Zhang Z, Gonzalez CM, Damania B, Cullen BR. Kaposi's sarcoma-associated herpesvirus expresses an array of viral microRNAs in latently infected cells. Proceedings of the National Academy of Sciences of the United States of America. 2005; 102(15):5570-5575.

[202] Omoto S, Ito M, Tsutsumi Y, et al. HIV-1 nef suppression by virally encoded microRNA. Retrovirology. 2004;1:44.

[203] Omoto S, Fujii YR. Regulation of human immunodeficiency virus 1 transcription by nef microRNA. Journal of General Virology. 2005;86(3):751-755.

[204] Bennasser Y, Le S-Y, Benkirane M, Jeang K-T. Evidence that HIV-1 encodes an siRNA and a suppressor of RNA silencing. Immunity. 2005;22(5):607-619.

[205] Sullivan CS, Grundhoff AT, Tevethia S, Pipas JM, Ganem D. SV40-encoded microRNAs regulate viral gene expression and reduce susceptibility to cytotoxic T cells. Nature. 2005;435(7042):682-686.

[206] Lu S, Cullen BR. Adenovirus VA1 noncoding RNA can inhibit small interfering RNA and microRNA biogenesis. Journal of Virology. 2004;78(23):12868-12876.

[207] Gatignol A, Laine S, Clerzius G. Dual role of TRBP in HIV replication and RNA interference: viral diversion of a cellular pathway or evasion from antiviral immunity? Retrovirology. 2005;2:65. 

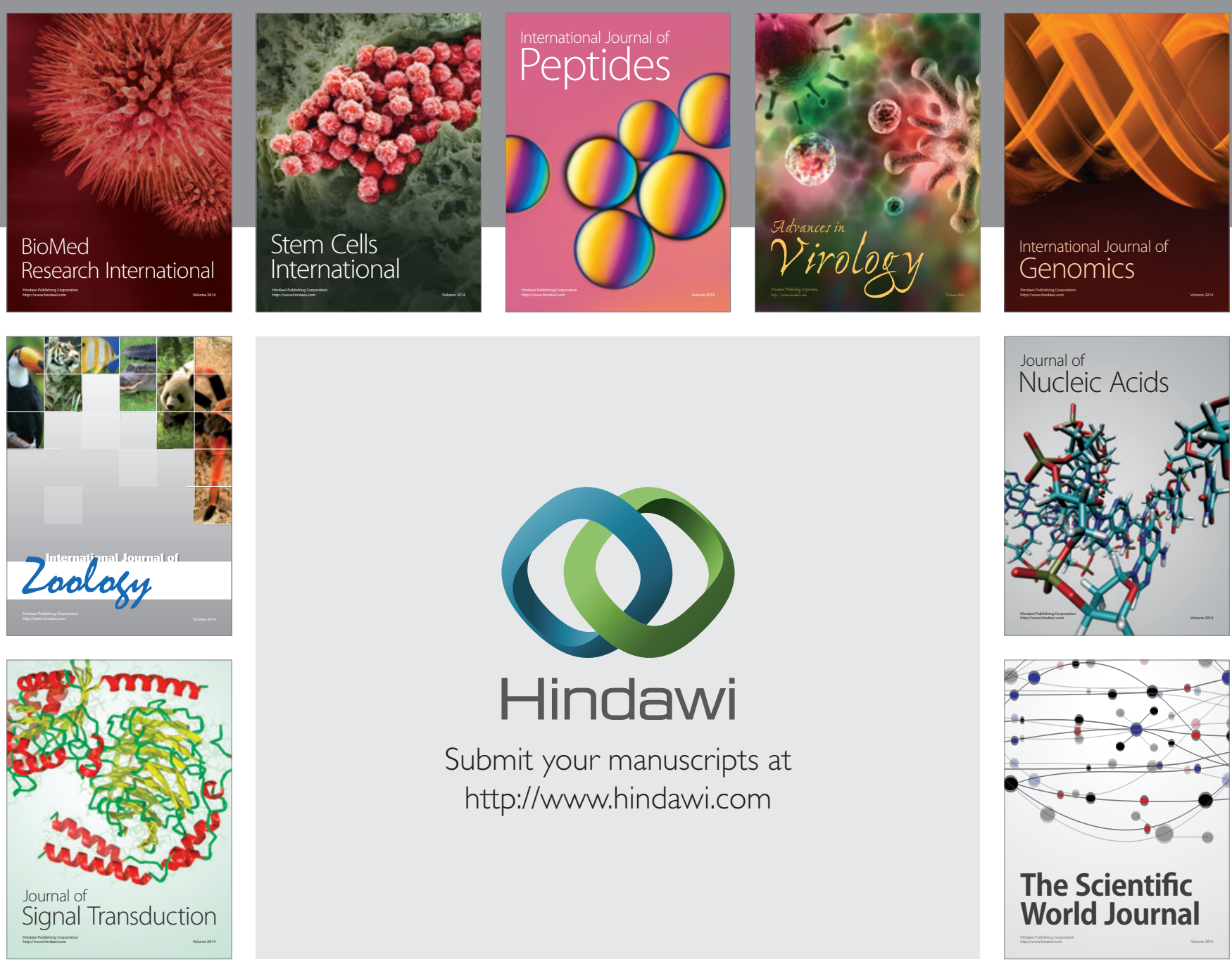

Submit your manuscripts at

http://www.hindawi.com
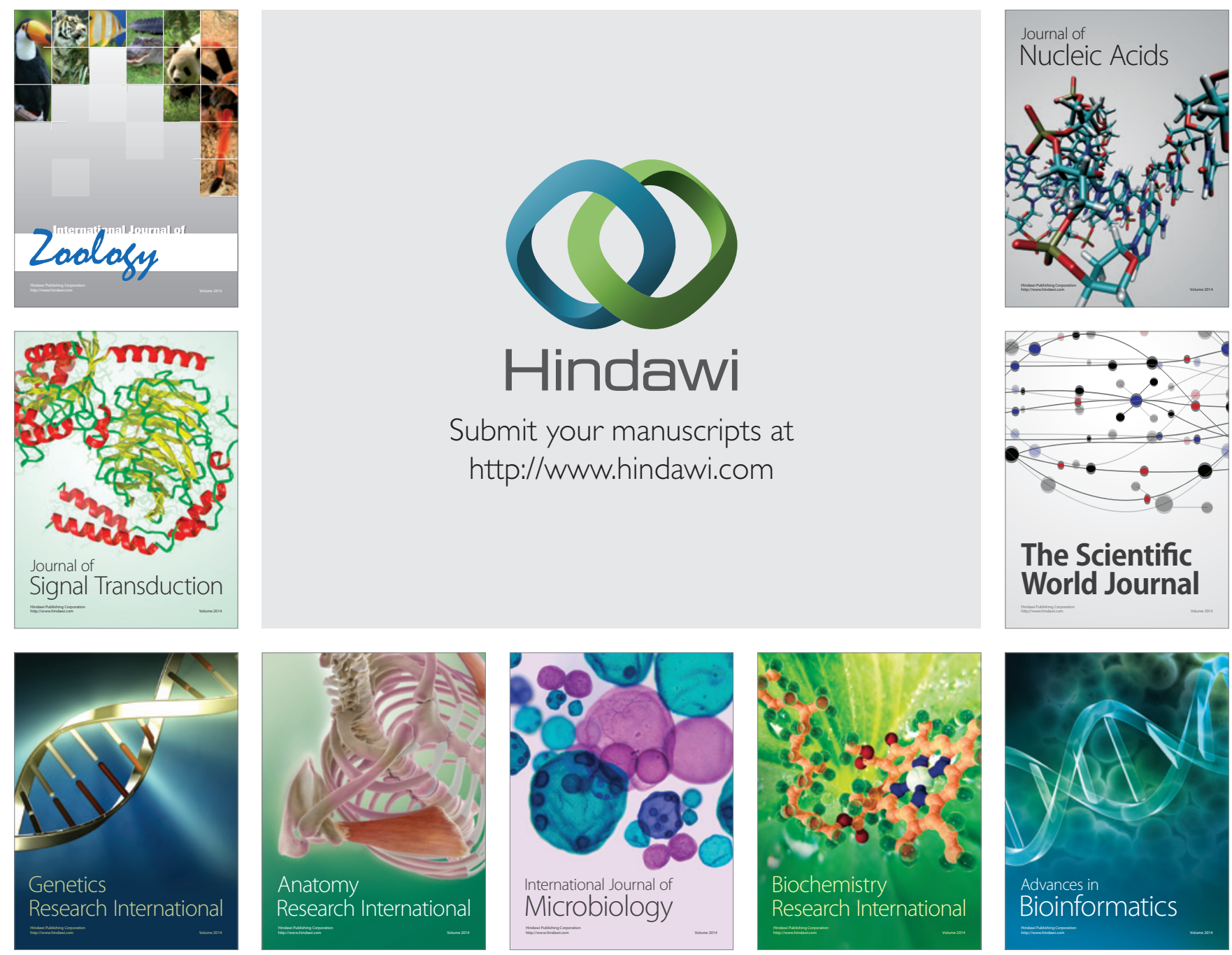

The Scientific World Journal
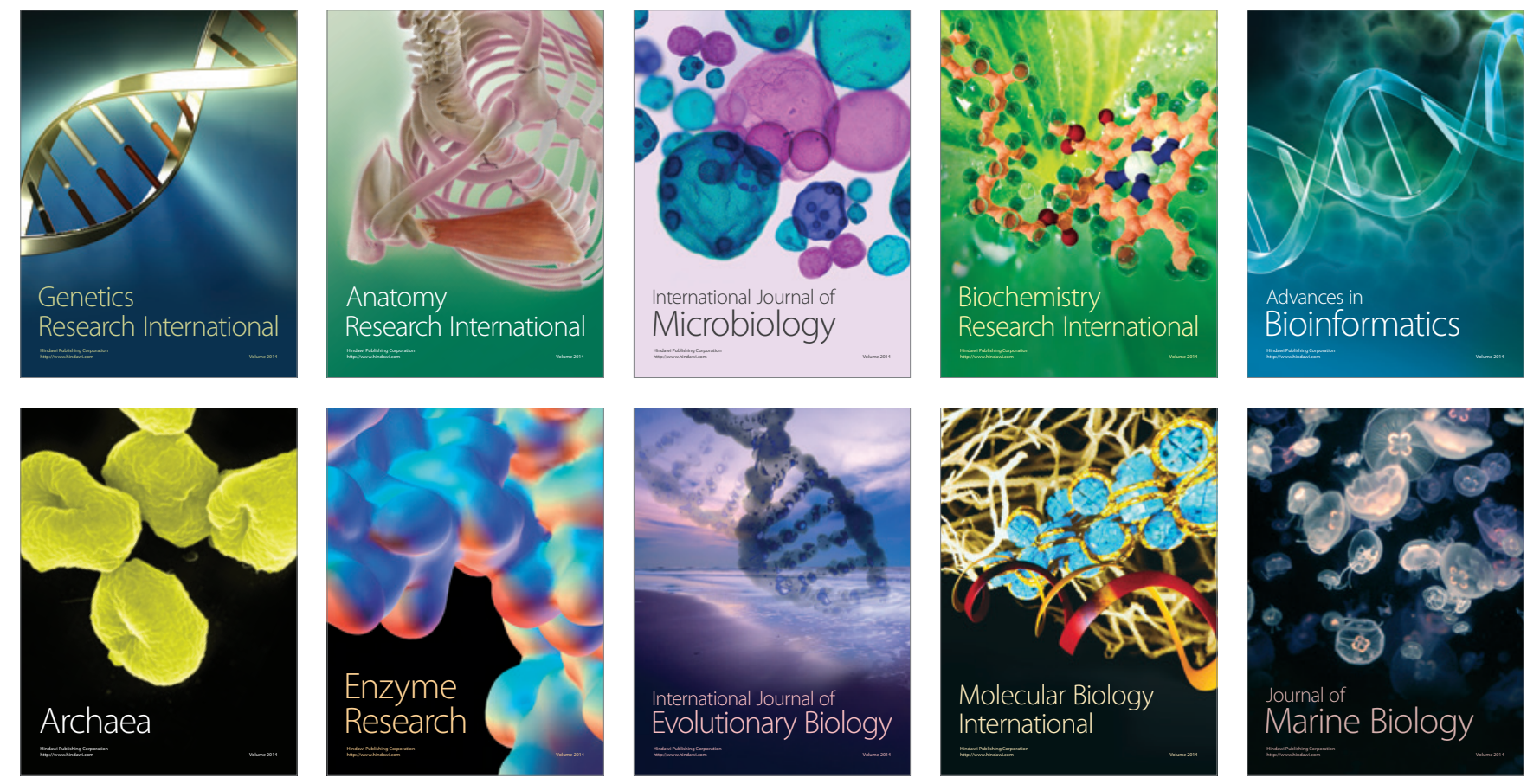